\title{
Developing a stronger and better - tasting mushroom with unique features
}

An innovative multi-disciplinary approach

Johan Baars ${ }^{1}$, Roland Mumm¹, Ineke Stijger ${ }^{1}$, Jasper Engel ${ }^{1} \&$ Ron Wehrens ${ }^{1}$

1 Wageningen University \& Research

Dit onderzoek is in opdracht van Topsector Tuinbouw en Uitgangsmaterialen uitgevoerd door de Stichting Wageningen Research (WR), business unit Plant Breeding, in het kader van beleidsondersteunend onderzoeksthema Duurzame Plantaardige Productie (projectnummer BO-00.50-002-046).

WR is een onderdeel van Wageningen University \& Research, samenwerkingsverband tussen Wageningen University en de Stichting Wageningen Research.

Wageningen, Maart 2019

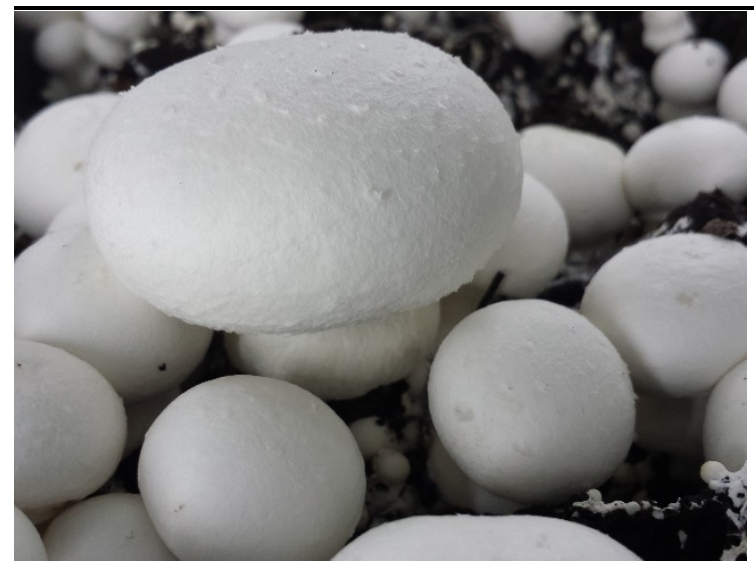

Rapport 2019-1 
J ohan Baars, Roland Mumm, Ineke Stijger, Jasper Engel \& Ron Wehrens, 2019. Developing a stronger and better - tasting mushroom with unique features; An innovative multi-disciplinary approach. Wageningen Research, Rapport 2019-1. 39 blz.; 32 fig.; 4 tab.; 2 ref.

Dit rapport is gratis te downloaden op https://doi.org/10.18174/477445.

Samenvatting: Dit verslag geeft een samenvatting van in het kader van project BO-50-002-046 verrichtte werkzaamheden met betrekking tot de ontwikkeling van een model dat smaak van champignons kan voorspellen op basis van metabolietsamenstelling.

Trefwoorden: Champignon, Agaricus bisporus, smaak

(C) 2019 Wageningen, Stichting Wageningen Research, Wageningen Plant Research, Business unit Plant Breeding, Postbus 16, 6700 AA Wageningen; T 03174828 36; www.wur.nl/plant-research

KvK: 09098104 te Arnhem

VAT NL no. 8113.83.696.B07

Stichting Wageningen Research. Alle rechten voorbehouden. Niets uit deze uitgave mag worden verveelvoudigd, opgeslagen in een geautomatiseerd gegevensbestand, of openbaar gemaakt, in enige vorm of op enige wijze, hetzij elektronisch, mechanisch, door fotokopieën, opnamen of enige andere manier zonder voorafgaande schriftelijke toestemming van Stichting Wageningen Research.

Stichting Wageningen Research is niet aansprakelijk voor eventuele schadelijke gevolgen die kunnen ontstaan bij gebruik van gegevens uit deze uitgave.

Rapport 2019-1 


\section{Inhoud}

$\begin{array}{ll}\text { Woord vooraf } & 5\end{array}$

$\begin{array}{ll}\text { Samenvatting } & 8\end{array}$

$\begin{array}{llr}1 & \text { Selectie en teelt van champignon-rassen. } & 10\end{array}$

$2 \quad$ Opzet van het onderzoek 12

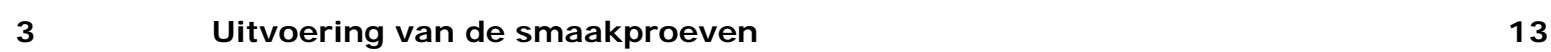

3.1 Analyse van smaak door een sensorisch panel 13

3.2 Statistische analyse van de data afkomstig van de sensorische panels. $\quad 15$

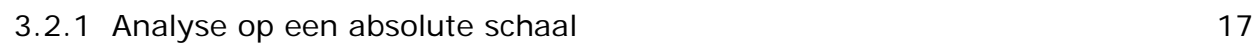

3.2.2 Analyse van smaakattributen ten opzichte van ras A15. 18

4

$\begin{array}{ll}\text { Analyse op aanwezige metabolieten } & 20\end{array}$

$\begin{array}{lll}4.1 & \text { Analyse op metabolieten } & 20\end{array}$

4.2 Statistische analyse van metaboliet data. $\quad 20$

4.2.1 Mannitol 20

4.2.2 Vluchtige verbindingen $\quad 20$

$\begin{array}{ll}4.2 .3 \text { Nucleotiden } & 21\end{array}$

$\begin{array}{ll}4.2 .4 \text { Polaire verbindingen } & 21\end{array}$

$5 \quad$ Koppeling van smaak attributen aan metabolieten $\quad 23$

5.1 Gebruik makend van scores voor smaakattributen op een absolute schaal 23

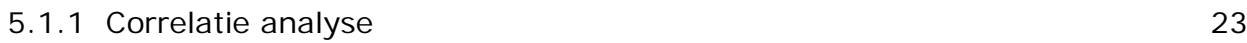

$\begin{array}{ll}5.1 .2 \text { Linear modeling } & 23\end{array}$

5.2 Smaakattributen relatief tot referentie ras A15. 23

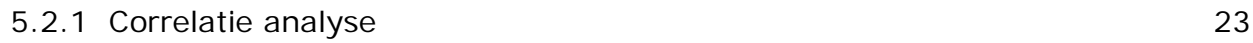

5.2.2 Lineaire modellering 23

$\begin{array}{lll}5.3 & \text { Conclusies } & 27\end{array}$

Pogingen om de waarnemingen door het sensorisch panel te verbeteren. 28

6.1 Teelt van champignonrassen. $\quad 28$

6.2 Beoordeling door het sensorisch panel $\quad 28$

6.2.1 Statistische analyse van de resultaten $\quad 28$

6.3 Analyse van de metabolieten 30

6.4 Koppeling van smaak attributen aan metabolieten 30

6.5 Conclusie $\quad 34$

$\begin{array}{ll}\text { Literatuur } & 36\end{array}$ 



\section{Woord vooraf}

Nederland is een van de grootste producenten van champignons in de wereld. Er zijn echter de laatste decennia slechts weinig nieuwe champignon-gebaseerde producten op de markt gekomen. Dit project beoogt een aanzet te leveren tot de ontwikkeling van champignonrassen die zich onderscheiden in smaak en die zich daarnaast zichtbaar onderscheiden van de huidige commercieel verkrijgbare champignons. De reden om te denken dat dat mogelijk is ligt in een onderzoek dat met financiering van het Ministerie van Economische Zaken is uitgevoerd (project nummer KB-15-001021). Baars et al. (2015) beschreven de resultaten van een screening van 8 genetisch verschillende champignonrassen op smaakverschillen. Hiervoor werden de rassen geteeld op een reguliere compost en dekaarde. Twee rassen werden daarnaast geteeld op compost met een dekaarde waaraan calciumchloride was toegevoegd om de osmotische waarde te verhogen. Met een toevoeging van calciumchloride aan dekaarde werd beoogd het droge stof gehalte van de champignons te verhogen en daardoor smaakverschillen te laten ontstaan.

$\mathrm{Na}$ de oogst werden de champignons door Scelta in hun eigen sap gesteriliseerd, zonder de toevoeging van additieven. Vervolgens werden ze verpakt in eco-pouches en bewaard bij kamertemperatuur tot het moment waarop ze werden aangeboden aan het consumenten panel van WUR Glastuinbouw. Het consumentenpanel kreeg champignons van de verschillende rassen/behandelingen verwarmd aangeboden (90 sec. op 500 Watt in een magnetron) waarna ze op een schaal van 1 tot 100 konden aangeven hoe lekker ze het product vonden. De resultaten van de testen lieten statistisch significante verschillen zien tussen de behandelingen. Champignons van de rassen die geteeld werden op dekaarde met calciumchloride kregen de hoogste scores. Één van de rassen die op gewone dekaarde werden geteeld behaalde een vergelijkbare score met de rassen die op dekaarde met calciumchloride werden geteeld.

Toen eenmaal duidelijk was geworden dat consumenten smaakverschillen tussen champignonrassen konden waarnemen, is besloten om de proef te herhalen (Baars et al., 2016) Hiervoor werden drie rassen (twee commercieel verkrijgbare en één wildisolaat) wederom geteeld op compost met reguliere dekaarde of dekaarde waaraan calciumchloride was toegevoegd. Champignons geproduceerd op de normale dekaarde hadden een droge stof gehalte van ongeveer $77 \mathrm{~g} / \mathrm{kg}$ versgewicht, terwijl de champignons die geoogst werden van dekaarde met clacium chloride een droge stof gehalte hadden van ongeveer $123 \mathrm{~g} / \mathrm{kg}$ versgewicht. Binnen een dag na oogsten werden de champignons geconserveerd in Eco pouches en bewaard tot analyse. Bij WUR Glastuinbouw werd een sensorisch panel met 40 leden getraind op het onderscheiden van de diverse aspecten van smaak van paddenstoelen. Een trainingssessie leverde een lijst met smaakattributen op die gebruikt werd voor de beoordeling van de smaak van de geconserveerde champignons. De smaak van champignons van de verschillende behandelingen (combinaties van champignonras en type dekaarde) werd in twee sessies beoordeeld. De resultaten van deze twee sessies verschilden van elkaar. Desalniettemin werden in beide sessies statistisch significante verschillen gevonden in stevigheid en sappigheid van de champignons. De verschillen in stevigheid en sappigheid leken samen te hangen met zowel verschillen tussen rassen en verschillen in het type dekaarde. Verder werden significante verschillen gevonden in het smaakaspect "gekookt ei" en deze leken vooral samen te hangen met het type dekaarde (wel of geen calciumchloride toegevoegd).

Van de champignons die werden aangeboden aan het smaakpanel werden kleine porties ingevroren in vloeibare stikstof en geanalyseerd op gehalten aan aminozuren, 5'-nucleotiden, mannitol en vluchtige verbindingen. De gehalten aan metabolieten op een versgewicht-basis werden sterk beïnvloed door het type dekaarde (wel of geen calciumchloride toegevoegd). Voor de meeste aminozuren en 5'nucleotiden werden verschillen in gehalten gevonden tussen de verschillende champignonrassen. Daarnaast werden in het algemeen hogere gehalten gevonden in de champignons afkomstig van een dekaarde waaraan calcium chloride was toegevoegd.

Er is gepoogd om de resultaten van het smaakpanel te koppelen aan de metabolite resultaten. Hoewel het een kleine dataset betreft, werden er correlaties gevonden tussen de smaakattributen stevigheid, gummi en gekookt ei enerzijds en de gehalten aan alanine, arginine en proline anderzijds. 
Als eerste stap voor toekomstig veredelingsonderzoek moeten metabolieten in champignons worden geïdentificeerd die voorspellende waarde hebben voor de smaak. Als dergelijke merker-moleculen betrouwbaar zijn geïdentificeerd, kan in een vervolgproject daadwerkelijk een veredelingstraject worden opgestart.

Het in dit rapport beschreven onderzoek heeft zich gericht op de identificatie van merker moleculen. 


\section{Samenvatting}

Nederland is een van de grootste producenten van champignons in de wereld. Er zijn echter de laatste decennia slechts weinig nieuwe champignon-gebaseerde producten op de markt gekomen. Dit project beoogt een aanzet te leveren tot de ontwikkeling van champignonrassen die zich onderscheiden in smaak en die zich daarnaast zichtbaar onderscheiden van de huidige commercieel verkrijgbare champignons. Als eerste stap voor dergelijk toekomstig veredelingsonderzoek moeten metabolieten in champignons worden geïdentificeerd die voorspellende waarde hebben voor de smaak. Als dergelijke merker-moleculen betrouwbaar zijn geïdentificeerd, kan in een vervolgproject daadwerkelijk een veredelingstraject worden opgestart.

Uit een collectie van ongeveer 250 wildisolaten van de champignons is een selectie gemaakt van 43 isolaten die de gehele genetische variatie van de collectie min of meer omvatten. Deze isolaten zijn opgekweekt in 6 verschillende teeltproeven en aangeboden aan een sensorisch panel dat verschillende aspecten van de smaak heeft beoordeeld. Statistische analyse van de resultaten laat zien dat hoewel voor de meeste isolaten de smaak erg lijkt op de commercieel beschikbare witte champignons, er een aantal isolaten zijn die anders smaken. Dezelfde champignons die zijn aangeboden aan het sensorisch panel zijn daarnaast onderzocht op metaboliet samenstelling. Het is nog niet mogelijk gebleken om de verschillen in smaak te koppelen aan specifieke metaboliet samenstellingen in de champignons. Een van de oorzaken is de grote variatie in beoordeling van smaakaspecten door het sensorisch panel. Daarnaast bleek bij vergelijking van de verschillende batches van controle ras A15, ook batch tot batch variatie op te treden in metabolietgehalten.

Vervolgens is geprobeerd om de variatie in beoordeling door het sensorisch smaakpanel te verminderen door:

- Veel minder rassen aanbieden aan het sensorisch panel

- Rassen met grootst mogelijk verschil in smaak aanbieden

- Interne herhalingen aanbieden als extra controle.

Helaas bleek ook bij deze opzet het niet mogelijk om de beoordeling van de verschillende aspecten van champignonsmaak te koppelen aan merkermoleculen. 


\section{Selectie en teelt van champignon- rassen.}

WUR Plant Breeding beschikt over een collectie van ongeveer 250 wildisolaten van champignon. In een voorgaand project is deze collectie met behulp van Single Nucleotide Polymorphism (SNP) merkers gegenotypeerd. Op basis van deze genotypering is een selectie gemaakt van 43 wildisolaten (zie Tabel 1). Deze selectie van 43 isolaten representeert nagenoeg de gehele genetische variatie van de collectie. Bij het maken van de selectie is rekening gehouden met de vraag of de isolaten voldoende champignons produceren. Vervolgens is begonnen met het maken van broed door de teeltproeven. In de periode maart-juni 2017 werden 3 teeltproeven uitgevoerd waarin alle champignonrassen werden opgekweekt tot productie van champignons. Aangezien een smaakpanel slechts 8 monsters naast elkaar kan testen in een proefsessie, moesten bij het afventileren van de teelten zo gewerkt worden dat per proefsessie telkens 7 wildisolaten en commercieel ras A15 kon worden aangeboden. De 43 wildisolaten en commercieel ras A15 werden aan een sensorisch panel van WUR Glastuinbouw aangeboden in 6 proefsessies.

De teelten van de diverse champignon wild-isolaten is relatief probleemloos verlopen. Slechts 3 van de 43 rassen konden niet worden aangeboden aan het smaakpanel; MES 01537 (te weinig productie), MES 01575 (eveneens te weinig productie) en MES 01675 (goede productie, maar te laat voor de smaaktest). Van alle rassen werden uitsluitend champignons geproduceerd in de eerste vlucht aangeboden aan het sensorisch panel. 
Tabel 1. Overzicht van de op smaak geteste wildisolaten van champignon

\begin{tabular}{|c|c|c|c|c|}
\hline Behand. & Coll. Nr. & $\begin{array}{l}\text { Teelt } \\
1+2\end{array}$ & $\begin{array}{l}\text { Teelt } \\
3+4\end{array}$ & $\begin{array}{l}\text { Teelt } \\
5+6\end{array}$ \\
\hline 1 & Sylvan A15 (het huidige veelgebruikte witte champignonras) & $\mathrm{x}$ & $x$ & $x$ \\
\hline 2 & Heirloom (het huidige veelgebruikte bruine champignonsras) & $x$ & & \\
\hline 3 & $\begin{array}{l}\text { C9 (het bruine champignonras dat tot voor } 7 \text { of } 8 \text { jaar geleden } \\
\text { veel geteeld werd) }\end{array}$ & $\mathrm{x}$ & & \\
\hline 4 & MES 01483 & $x$ & & \\
\hline 5 & MES 02956 & $x$ & & \\
\hline 6 & MES 01501 & $\mathrm{x}$ & & \\
\hline 7 & MES 01509 & $x$ & & \\
\hline 8 & MES 01512 & $x$ & & \\
\hline 9 & MES 01515 & $\mathrm{x}$ & & \\
\hline 10 & MES 01516 & $x$ & & \\
\hline 11 & MES 01535 & $x$ & & \\
\hline 12 & MES 01537 & $x$ & & \\
\hline 13 & MES 01542 & $x$ & & \\
\hline 14 & MES 01544 & $x$ & & \\
\hline 15 & MES 01545 & $x$ & & \\
\hline 16 & MES 01554 & & $x$ & \\
\hline 17 & MES 01562 & & $x$ & \\
\hline 18 & MES 01563 & & $x$ & \\
\hline 19 & MES 01569 & & $x$ & \\
\hline 20 & MES 01575 & & $x$ & \\
\hline 21 & MES 01579 & & $x$ & \\
\hline 22 & MES 01584 & & $x$ & \\
\hline 23 & MES 01637 & & $x$ & \\
\hline 24 & MES 01651 & & $x$ & \\
\hline 25 & MES 01675 & & $x$ & \\
\hline 26 & MES 01689 & & $x$ & \\
\hline 27 & MES 01706 & & $x$ & \\
\hline 28 & MES 01733 & & $x$ & \\
\hline 29 & MES 01751 & & $x$ & \\
\hline 30 & MES 01768 & & & $x$ \\
\hline 31 & MES 01775 & & & $x$ \\
\hline 32 & MES 01800 & & & $x$ \\
\hline 33 & MES 01806 & & & $x$ \\
\hline 34 & MES 01809 & & & $x$ \\
\hline 35 & MES 01812 & & & $x$ \\
\hline 36 & MES 01814 & & & $x$ \\
\hline 37 & MES 01856 & & & $x$ \\
\hline 38 & MES 01901 & & & $x$ \\
\hline 39 & MES 01914 & & & $x$ \\
\hline 40 & MES 01919 & & & $x$ \\
\hline 41 & MES 01926 & & & $x$ \\
\hline 42 & MES 01934 & & & $x$ \\
\hline 43 & MES 01945 & & & $x$ \\
\hline
\end{tabular}




\section{Opzet van het onderzoek}

Figuur 1 geeft een overzicht van het plan van aanpak voor de ontwikkeling van een smaakmodel voor champignons. De champignons die voortkomen uit de teelten, worden aangeboden aan een sensorisch panel voor een waardering van verschillende aspecten (attirbuten) van hun smaak. Dezelfde champignons die worden aangeboden aan het sensorisch panel, worden bemonsterd voor analyse van vluchtige en niet vluchtige metabolieten.

$\mathrm{Na}$ een statistische analyse van de data afkomstig van het sensorisch panel en een statistische analyse van de data afkomstig van de metabolietanalyses, wordt geprobeerd om deze te combineren in een model dat op basis van metaboliet samenstelling een smaak kan voorspellen.

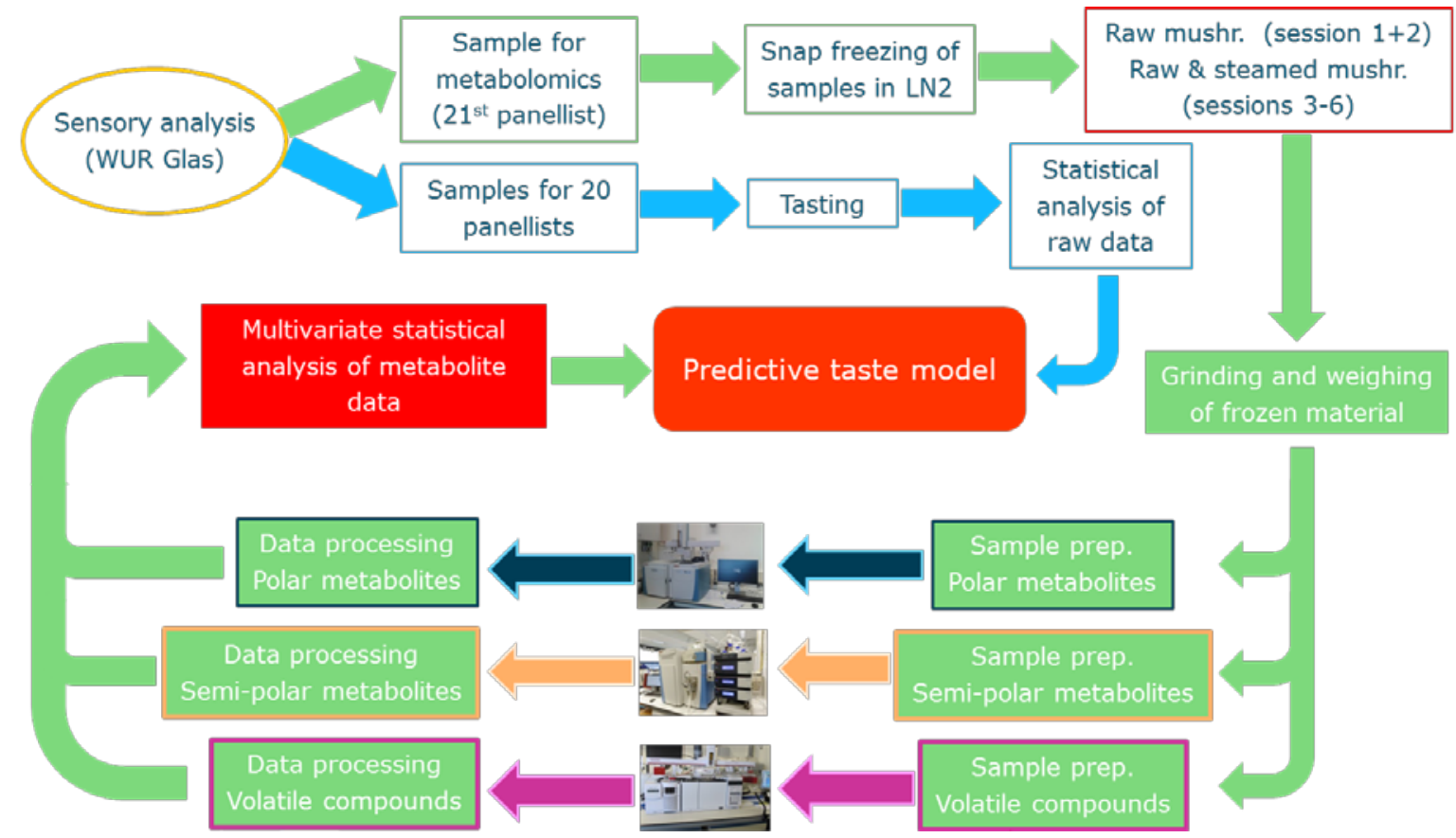

Figuur 1. Schematisch overzicht van de methode voor analyse van smaak en metabolietgehalten en de koppeling in een voorspellend model voor smaak. 


\section{$3 \quad$ Uitvoering van de smaakproeven}

\subsection{Analyse van smaak door een sensorisch panel}

Voorafgaand aan het uitvoeren van de smaakproeven werd een sensorisch panel bestaande uit 40 personen getraind op het herkennen van de verschillende smaakattributen van champignon. Een lijst van smaakattributen van champignons wordt gegeven in Tabel 2.

Tabel 2. Smaak attributen voor het beoordelen van de smaak van champignon isolaten.

\begin{tabular}{|ll|}
\hline Smaak attributen voor het beoordelen van de smaak van champignon-isolaten \\
\hline - & stevigheid \\
\hline - & vummy \\
\hline - & sappigheid \\
\hline - & zoetheid \\
\hline - & zoutheid \\
\hline - & aroma aanwezigheid \\
\hline - & aroma oordeel \\
\hline - & paddenstoel aroma \\
\hline - & schimmel aroma \\
\hline - & muf/ gronderig aroma \\
\hline - & metalig aroma \\
\hline - & vleesbouillon aroma \\
\hline - & nootachtig aroma \\
\hline - & gekookt ei aroma \\
\hline & bitter \\
\hline & Prikkelend \\
\hline
\end{tabular}

$\mathrm{Na}$ het vaststellen van de lijst met smaak attributen werd in 6 opeenvolgende sessies de smaak van de aangeboden champignons beoordeeld. Per smaakproef werden 25 leden van het sensorisch panel uitgenodigd. De smaakproeven werden uitgevoerd met champignons die 4 minuten gestoomd waren in een stoomoven. Resultaten van deze beoordelingen zijn te zien in de spin diagrammen in Figuur 2

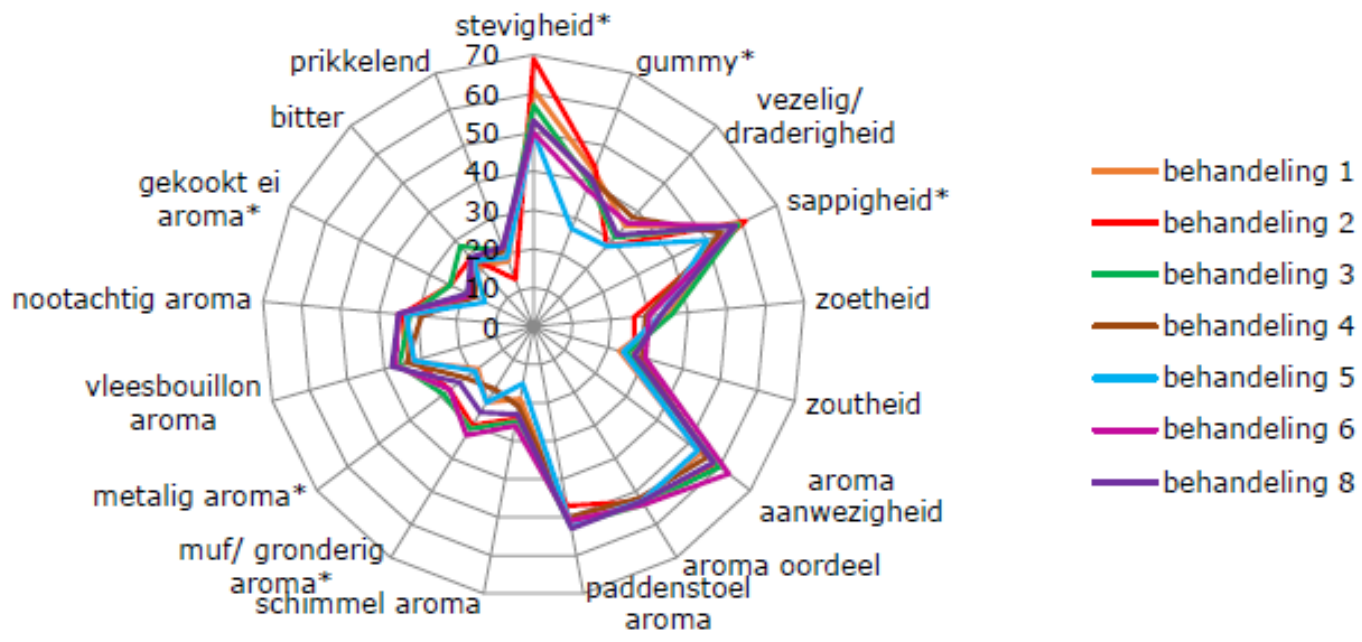

Figuur 2. Resultaten smaakbeoordelingen voor behandeling $1 \mathrm{t} / \mathrm{m} 6$ en 8 . Significante verschillen zijn met een * aangegeven. 


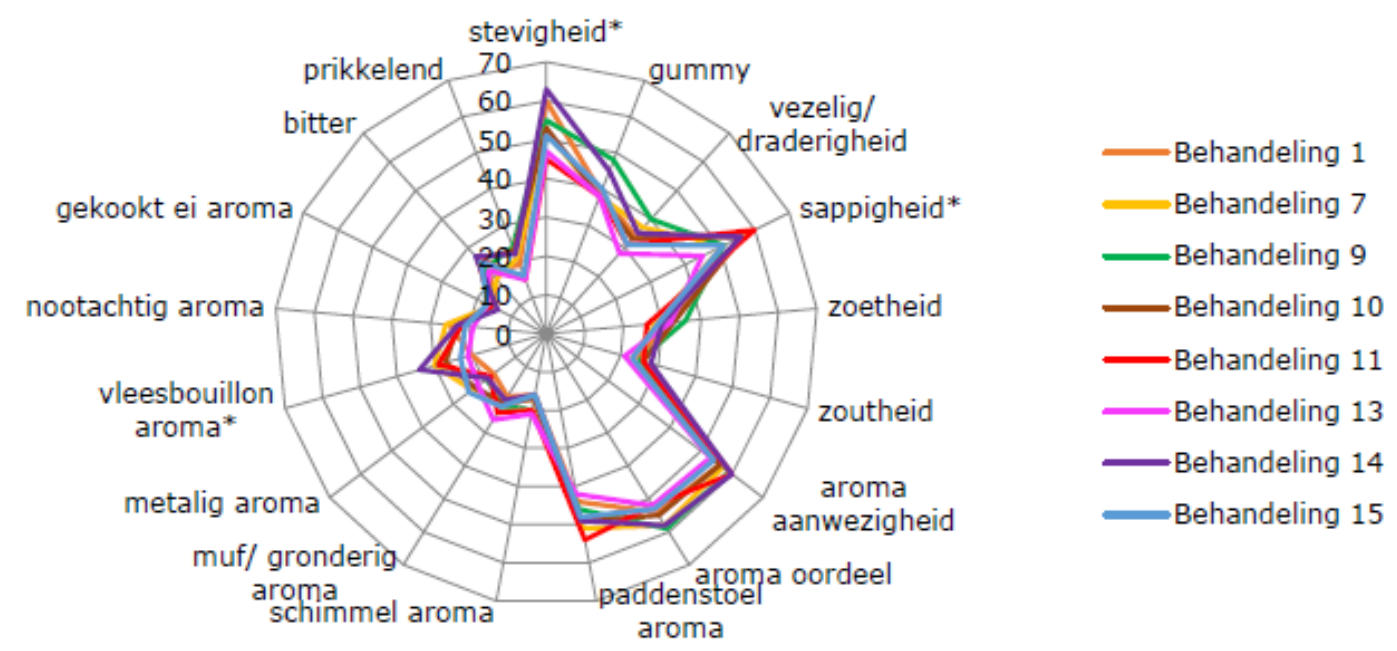

Figuur 5. Resultaten smaakbeoordelingen voor behandeling 1, 7, 9, 10, 11, 13 t/ m 15. Significante verschillen zijn met een $*$ aangegeven.

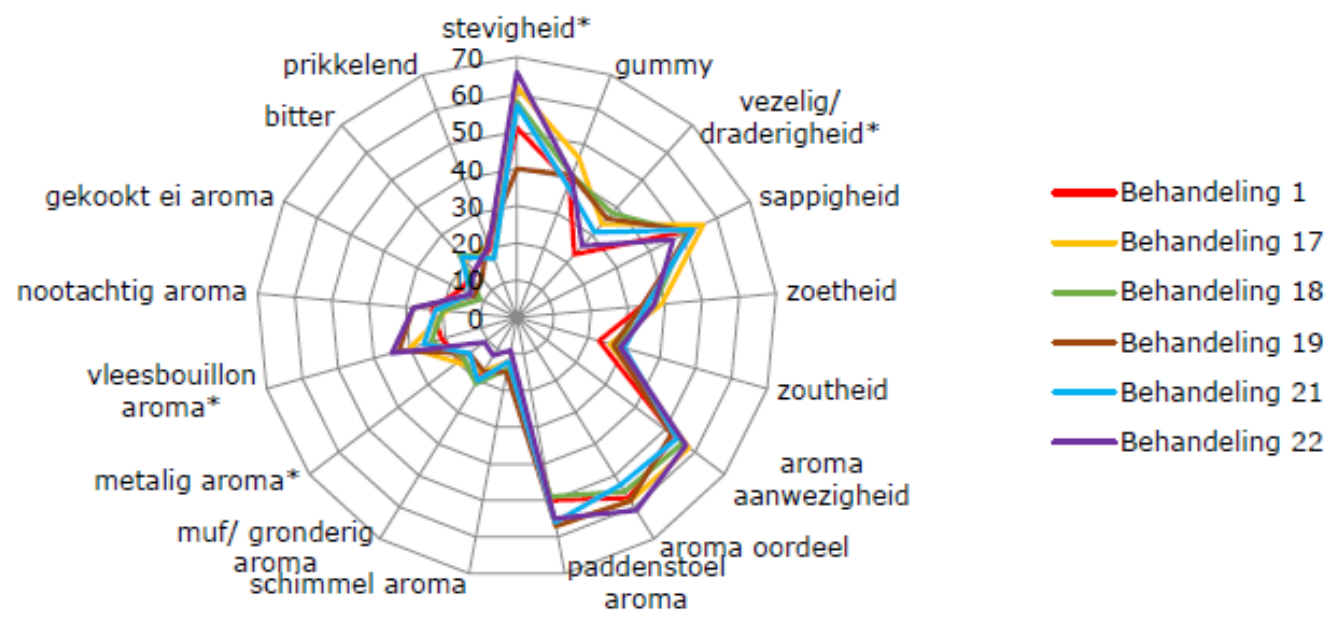

Figuur 5. Resultaten smaakbeoordelingen voor behandeling 1, 17, 18, 19, 21 en 22. Significante verschillen zijn met een * aangegeven.

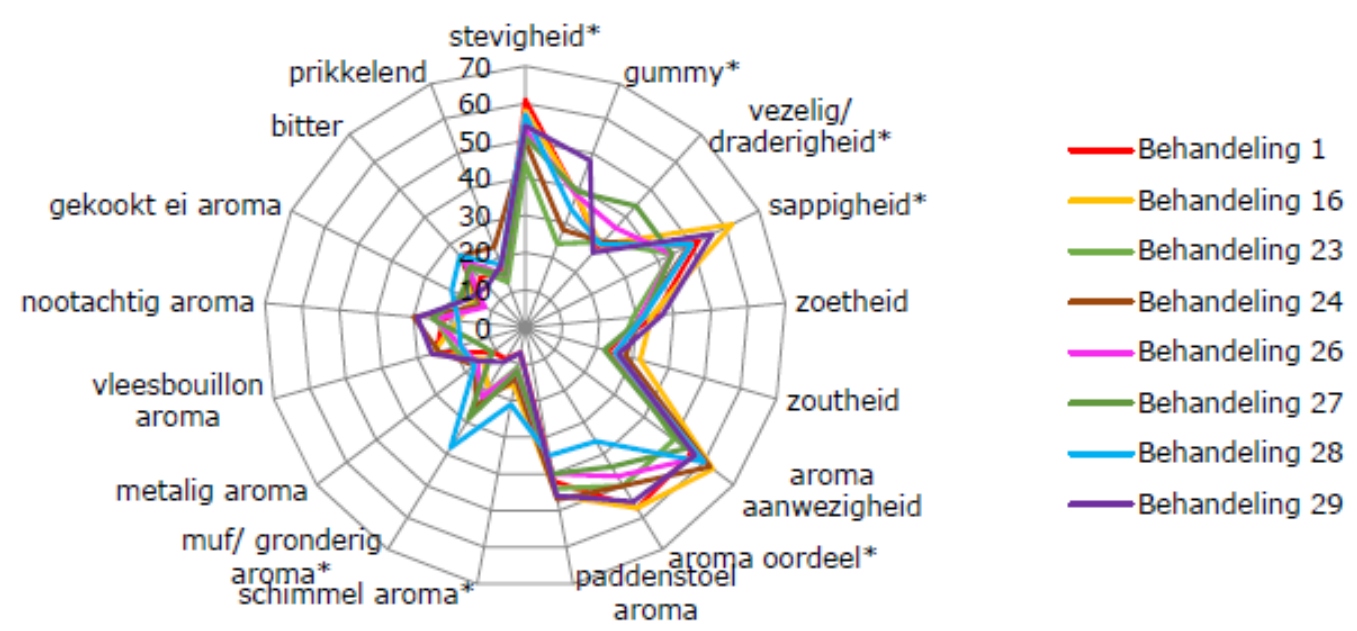

Figuur 5. Resultaten smaakbeoordeliongen voor behandeling 1, 16, 23, 24, 26, 27,28 en 29. Significante verschillen zijn met een * aangegeven. 


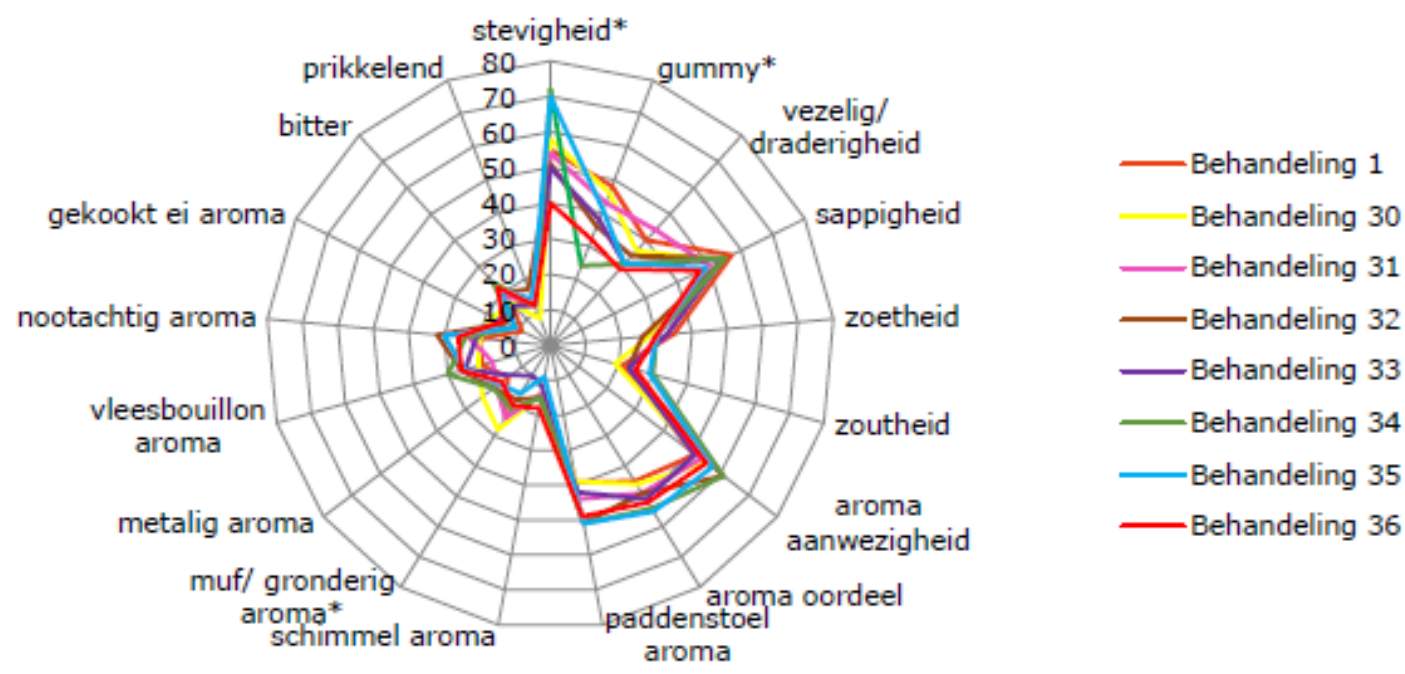

Figuur 7. Resultaten voor de smaakbeoordelingen voor behandeling 1 en 30 t/ m 36. Significante verschillen zijn met een * aangegeven.
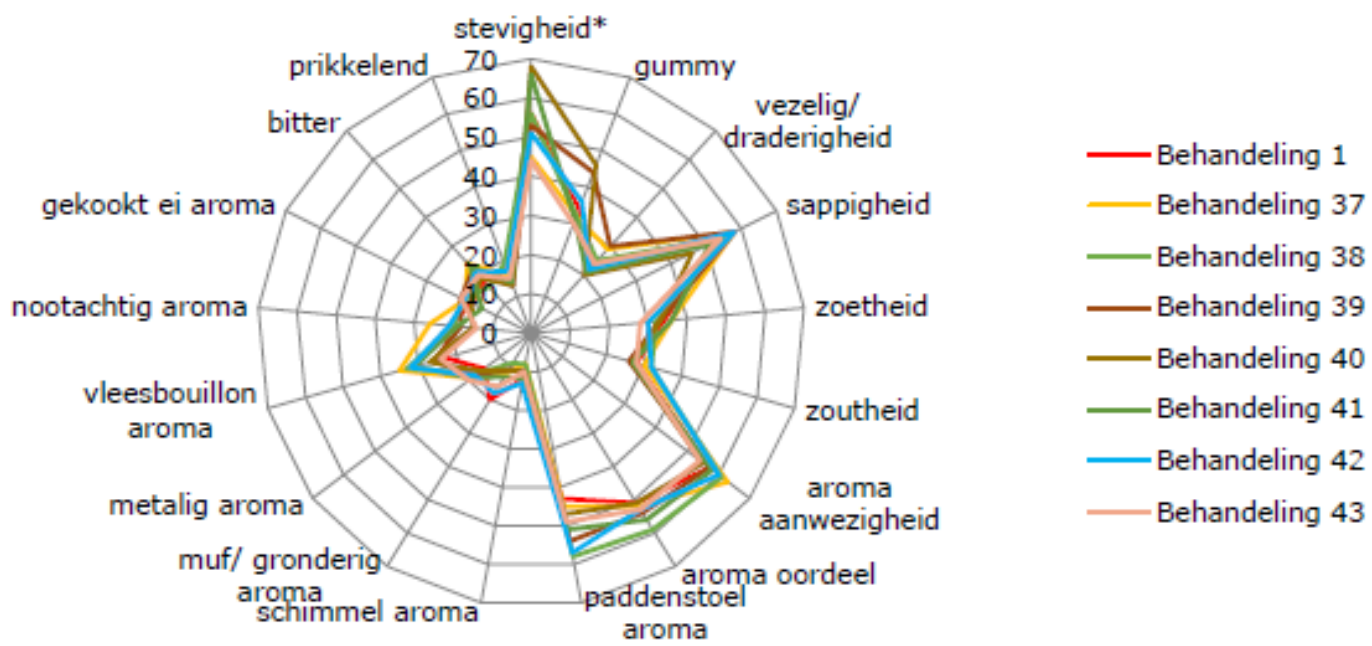

Figuur 7. Resultaten voor de smaakbeoordelingen voor behandeling 1 en 37 t/ m 43. Significante verschillen zijn met een $*$ aangegeven.

$\mathrm{t} / \mathrm{m}$ 7. De behandelingsnummers in deze figuren komen overeen met de behandelingsnummers in Tabel 1.

Zoals gezien kan worden in Figuur $1 \mathrm{t} / \mathrm{m}$ 6, werden smaakverschillen vooral gevonden voor de attirbuten Stevigheid, Gummy, Sappigheid, Muf/ gronderig aroma, Metalig aroma, Vleesbouillon aroma en Gekookt ei aroma. Voor de eigenschappen "zoetheid", "zoutheid", "bitter", "prikkelend" en "aroma aanwezigheid" werden geen significante verschillen gevonden. Het sensorisch panel kwam tot de conclusie dat behandeling 22 (MES 01584) het prettigste aroma had en een relatief goede weefselstevigheid.

\subsection{Statistische analyse van de data afkomstig van de sensorische panels.}

Sensorische panels staan bekend om de hoge mate van variabiliteit tussen de deelnemers in de panels en de varaibiliteit tussen de verschillende sessies van de sensorische panels. Men probeert de variabiliteit te verminderen door te werken met relatief grote panels. Het gemiddelde van de resultaten zou dan een redelijke inschatting moeten opleveren voor specifieke karakteristieken van 
het geteste monster. Tabel 3 geeft een overzicht van het aantal deelnemende leden van het sensorisch panel per sessie.

Tabel 3. Overzicht van het aantal deelnemende leden per sessie van het sensorisch panel

\begin{tabular}{|c|c|}
\hline Sessie & Aantal panelleden \\
\hline 1 & 25 \\
\hline 2 & 22 \\
\hline 3 & 23 \\
\hline 4 & 19 \\
\hline 5 & 18 \\
\hline 6 & 17 \\
\hline
\end{tabular}

Er zijn twee manieren denkbaar om de gegevens van het sensorisch panel te analyseren. De ene manier houdt in dat alle data bij elkaar worden genomen en dat een statistiek zoals het gemiddelde of de mediaan wordt gekozen om de smaakattributen te beschrijven. Het alternatief is dat alle data worden geanalyseerd ten opzichte van het referentie-ras A15 dat in alle sessies is meegenomen. Deze tweede methode geeft mogelijk wat reproduceerbaarder resultaten omdat een gedeelte van de bias wordt weggenomen.

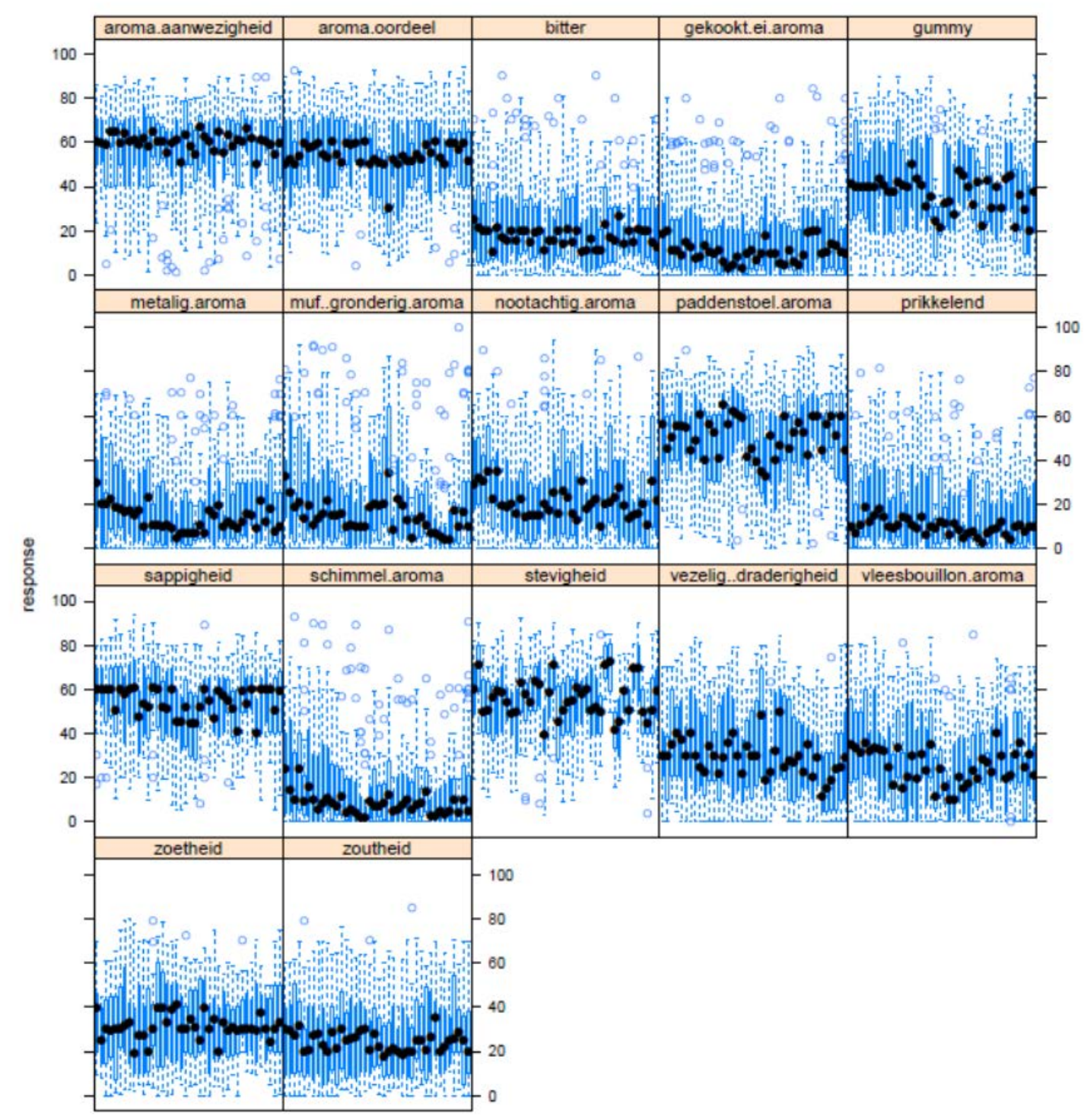

Figuur 8. Boxplot samenvatting van alle resultaten van het sensorisch panel. 


\subsubsection{Analyse op een absolute schaal}

Voor alle smaakattributen zijn in de dataset de resultaten voor de individuele testpersonen (geanonimiseerd) en voor de verschillende sessies beschikbaar. Deze gegevens zijn gebruikt om de variabiliteit tussen de champignonisolaten enerzijds en de leden van het sensorisch panel anderzijds in kaart te brengen. De ruwe data van het sensorisch panel zijn samengevat in de boxplots die worden weergegeven in Figuur 8. Zoals is te zien, is de variabiliteit aanzienlijk. Verder is te zien dat voor een aantal smaakattributen, er uitsluitend lage scores zijn gegeven. Zij zijn daarmee weinig informatief.
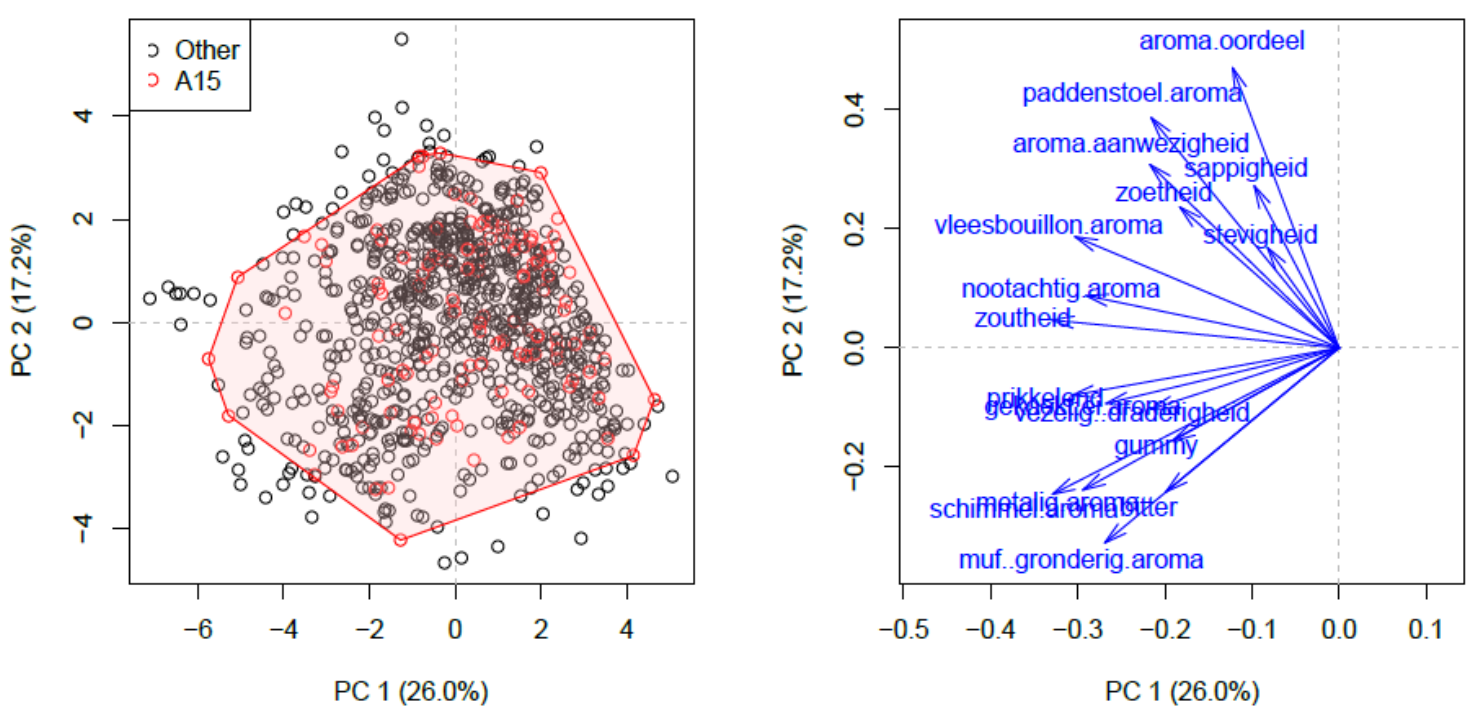

Figuur 9. Scoreplot (links) en loadingplot (rechts) van de data van het sensorisch panel. Het roze gebied omvat de waarden waartussen de data van A15 liggen

Figuur 9 toont op een andere manier hoe groot de variabiliteit is. In de score plot zijn de waarden voor A15 weergegeven en het gebied tussen deze waarden omvat de waarden van alle geteste wildisolaten van champignon. De beide assen in deze PCA plot verklaren respectievelijk 26 en $17 \%$ van de gemeten variatie.

In een Sammon plot kunnen we can de onderlinge afstanden tussen individuele variëteiten van champignon visualiseren, op basis van hun mediane sensory panel scores. In tegenstelling tot principal component analysis (PCA), is er geen percentage variatie gekoppeld aan een as en zijn beide asses even belangrijk. Net verschil is dat Sammon plots de werkelijke verschillen proberen te visualiseren, terwijl PCA slechts een gedeelte visualiseert. In een Sammon plot kunnen we dus zien welke variëteiten het sterkst van elkaar verschillen in smaak. Figuur 10 toont de Sammon plot voor de median van de smaakattributen voor individuele variëteiten. De meest interessante variëteiten zijn te vinden aan de randen van de plot; zij wijken het meest af van de "gemiddelde smaak" van de geteste variëteiten van champignon. Opvallend is dat het referentieras A15 erg dicht bij het centrum van de plot ligt (en dus de gemiddelde smaak sterk benadert).

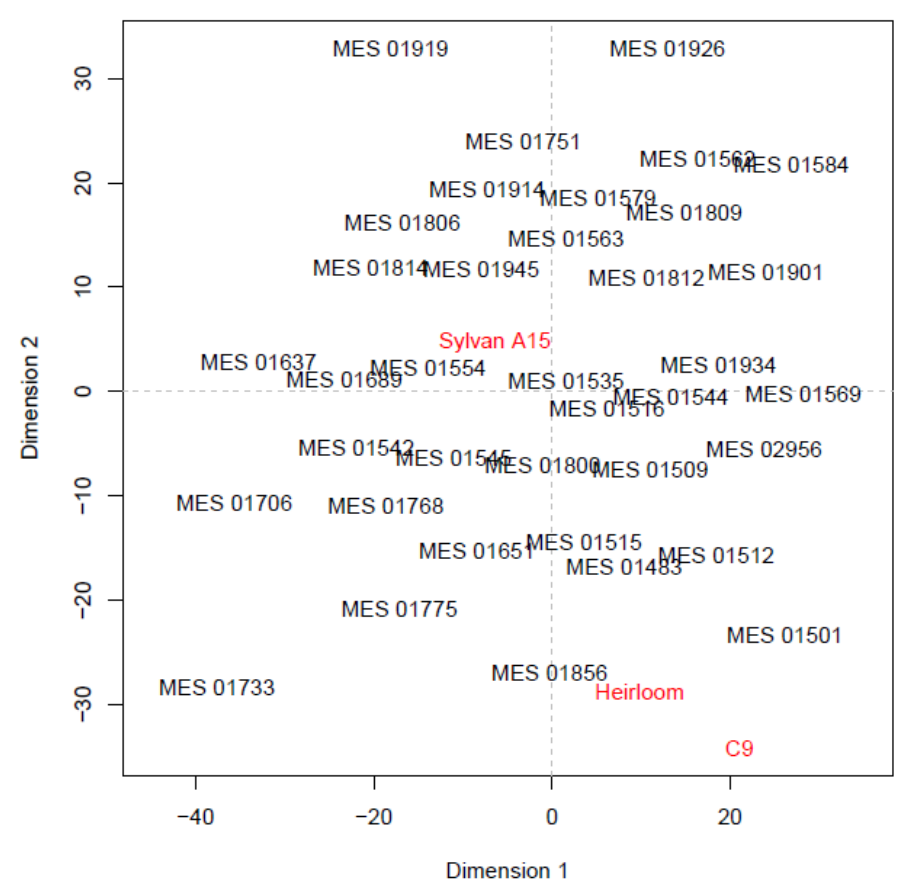

Figuur 10. Onderlinge afstand tussen variëteiten op basis van smaakattributen. 


\subsubsection{Analyse van smaakattributen ten opzichte van ras A15.}

Zoals al gezegd, kunnen de ruwe data van het sensorisch panel ook worden gebruikt om een analyse uit te voeren van de smaak ten opzichte van het referentieras A15. Hiervoor worden per sessie en per variëteit de waarden van A15 afgetrokken van de waarde van de andere variëteit. Dit heeft een aantal voordelen;

- $\quad$ Een gedeelte van de variatie wordt ge-elimineerd. Als twee panelleden dezelfde smaak met waarden van respectievelijk 40 en 60 eenheden waarderen, dan wordt dit verschil geelimineerd (mits de panelleden erg consistent zijn in hun waardering. Als echter twee panelleden hetzelfde verschil in een smaakattrribuut met respectievelijk 10 en 20 eenheden waarderen, dan blijft dit verschil bestaan.

- De nieuwe waarden worden minder begrensd. De originele schaal voor een smaakattribuut loopt van 0 naar 100. De omgerekende waarden liggen in de range van -100 tot +100 , maar liggen veel meer rond de 0 (het midden van de schaal).

Figuur 11 geeft een indruk hoe de smaakprofielen veranderen als ze worden omgerekend naar een smaakprofiel ten opzichte van A15. De meeste variatie in de gemiddelde waarde tussen de verschillende champignonisolaten is te zien bij de smaakattributen gummy, paddenstoelaroma, sappigheid, stevigheid, vezelig-draderigheid en vleesbouillon aroma.

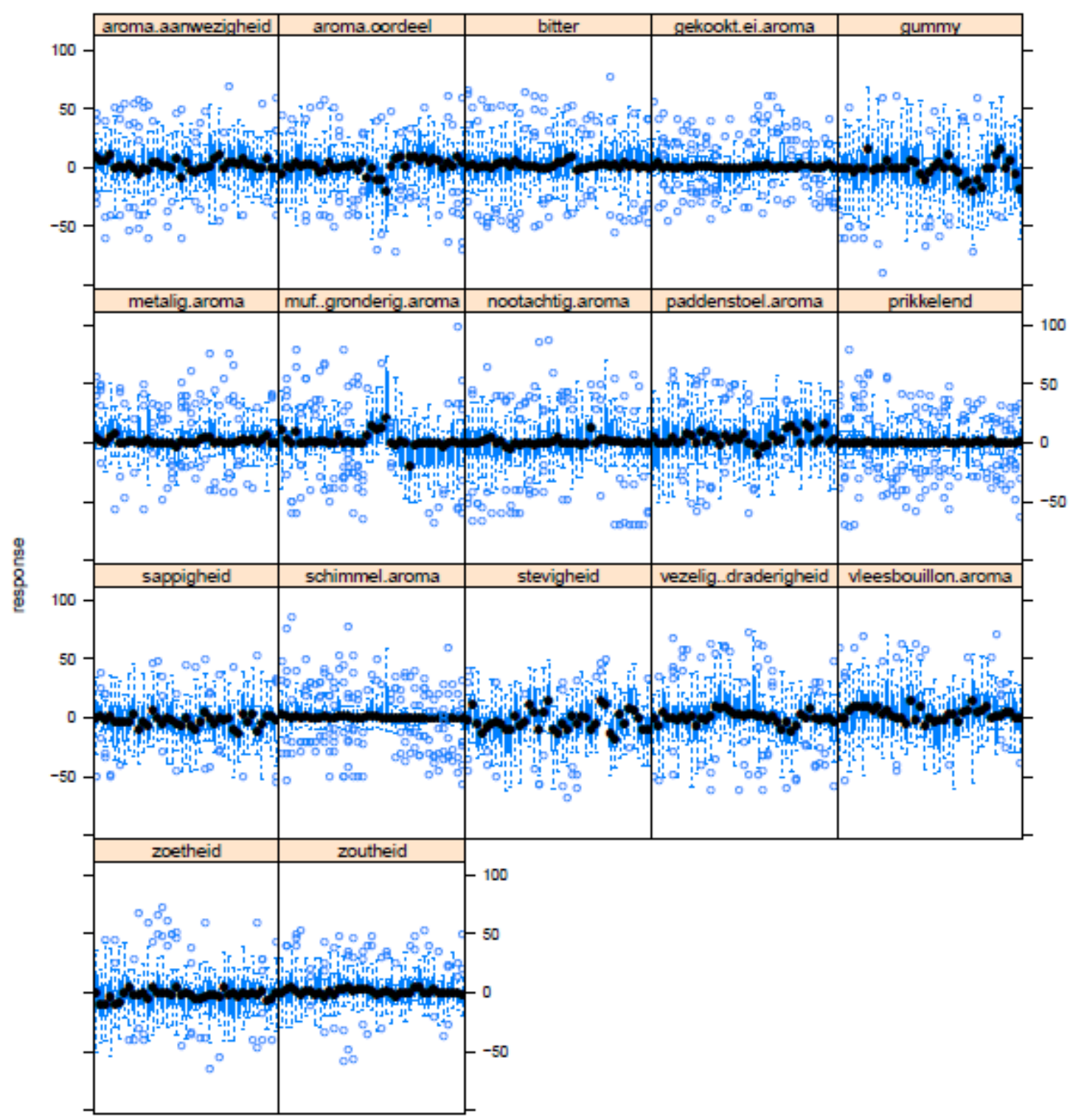

Figuur 11. Boxplot samenvatting van alle smaakattributen, relatief tot de standaard variëteit Sylvan A15. 


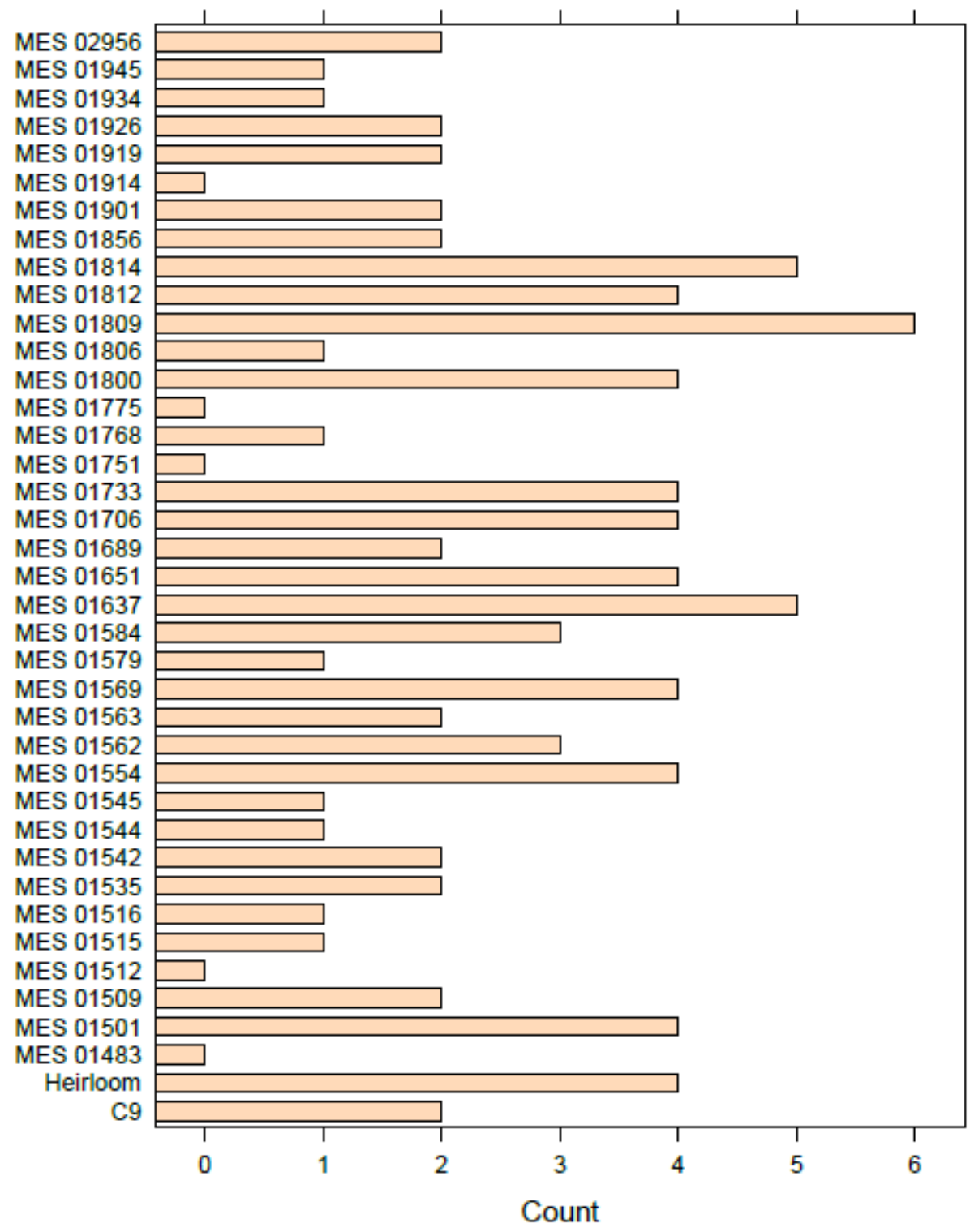

Figuur 12. Aantal maal dat de waardering voor een smaakattribuut significant $(p<0.05)$ afwijkt van die voor $A 15$.

In de omgewerkte dataset kan berekend worden hoe vaak een bepaald smaakattribuut een significant andere waarde heeft dan nul (m.a.w. hoe vaak een variëteit significant anders is dan A15). Dit wordt gedaan met een t-test. De resultaten zijn te zien in Figuur 12. Isolaat MES01809 wijkt op 6 smaakattributen significant af van de score voor A15 en is daarmee het meest afwijkend. MES 01914, MES01775, MES01751, enz., wijken slechts op één smaakattribuut significant af van A15. 


\section{$4 \quad$ Analyse op aanwezige metabolieten}

\subsection{Analyse op metabolieten}

Tijdens de smaakproeven zijn gestoomde en rauwe champignons in vloeibare stikstof ingevroren voor analyse van de metabolieten. Analyses werden verricht op polaire metabolieten zoals aminozuren, suikers (glucose, fructose, mannitol, etc.) en kleine organische zuren (malaat, citraat, etc), nucleotides (AMP, GMP, IMP) en semipolaire metabolieten. Dit leverde waarden voor een totaal van 318 metabolieten.

Vluchtige organische verbindingen werden ge-extraheerd middels solid phase microextraction (SPME) en geanalyseerd middels thermodesorption gas chromatography-mass spectrometry.

\subsection{Statistische analyse van metaboliet data.}

Voor alle platforms waarmee de metabolieten werden ge-analyseerd bleek een probleem te zijn opgetreden, in die zin dat er twee verschillende monstertypen werden aangeleverd; rauwe champignons en gestoomde champignons. Aangezien het stomen grote effecten had op de metabolietsamenstelling is de statistische analyse alleen uitgevoerd met de data afkomstig van de gestoomde champignons.

\subsubsection{Mannitol}

Mannitol, is een alcoholsuiker dat in hoge concentraties aanwezig is in champignons. Deze stof werd in een afzonderlijke bepaling gemeten. DE gevonden gehalten staan weergegeven in Figuur 13 . Er is een verschil van een factor 3 tussen de hoogste en de laagste waarde. Ongelukkig genoeg, laten ook de waarden voor mannitol in de herhalingen van standaardras A15 een aanzienlijke biologische variatie zien.

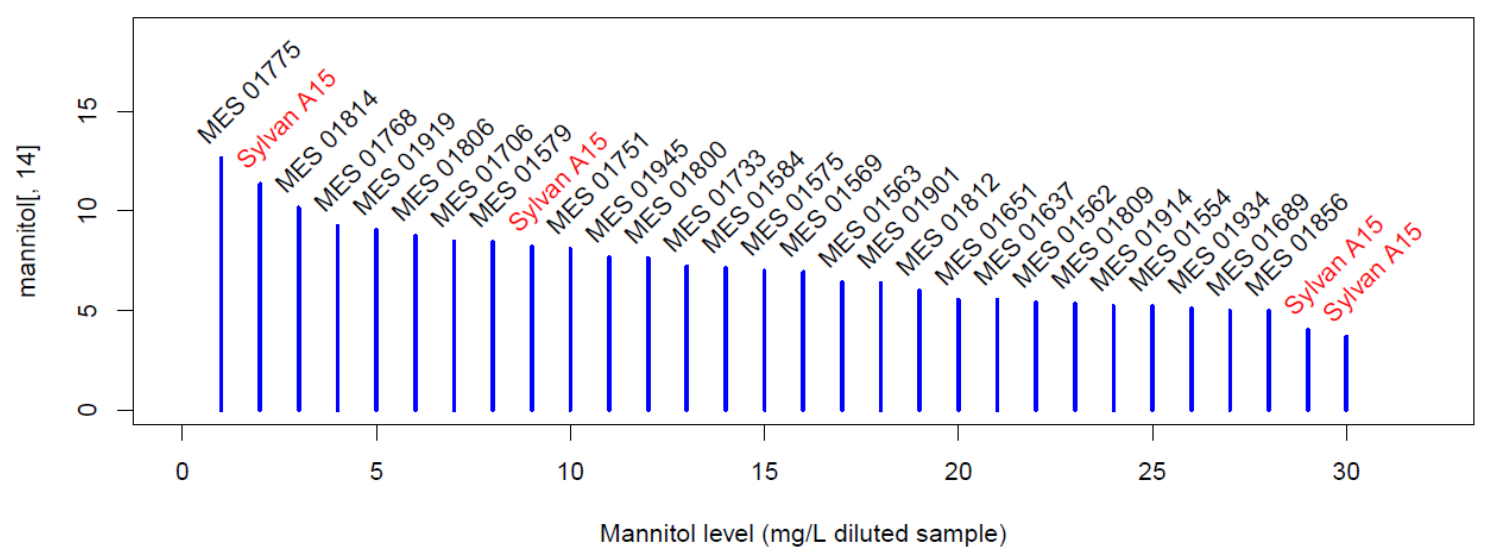

Figuur 13. Variatie in mannitol-gehalte van gestoomde champignons van ras A15

\subsubsection{Vluchtige verbindingen}

Het aantal vluchtige verbindingen in ongestoomde champignons is hoger dan in gestoomde champignons. Daarnaast zijn een aantal vluchtige metabolieten niet aanwezig in alle monsters van gestoomde champignons. Sommige metabolieten (12) zijn aanwezig in alle monsters, maar de meeste vluchtige metabolieten zijn slechts in een een paar monsters aanwezig. Als een metaboliet niet aanwezig was in een monster, heeft het de waarde 0 gekregen in de input file voor statistische 
analyse. Individuele champignonmonsters konden tussen 15 en $80 \%$ aan nulwaarden bevatten. Als gevolg daarvan werd in de statistische analyse alleen gewerkt met die metabolieten die in ten minste de helft van de monsters aanwezig waren. Figuur 16 toont een Sammon plot voor de vluchtige verbindingen. De A15 referentie is weergegeven met rode driehoekjes. Champignonisolaten die sterk verschillend waren van de oorsprong in de plot zijn apart vernoemd.

\subsubsection{Nucleotiden}

De data voor de nucleotide GMP, AMP en IMP worden weergegeven in de scatterplots in Figuur 15. De correlatie tussen GMP en AMP is erg hoog. De correlatie met IMP iets minder. De rauwe champignon (niet getoond) hebben erg late warden voor deze drie nucleotide. Blijkbaar zorgt het stomen voor het vrijmaken van deze nucleotiden uit de matrix
Sammon plot (volatiles)

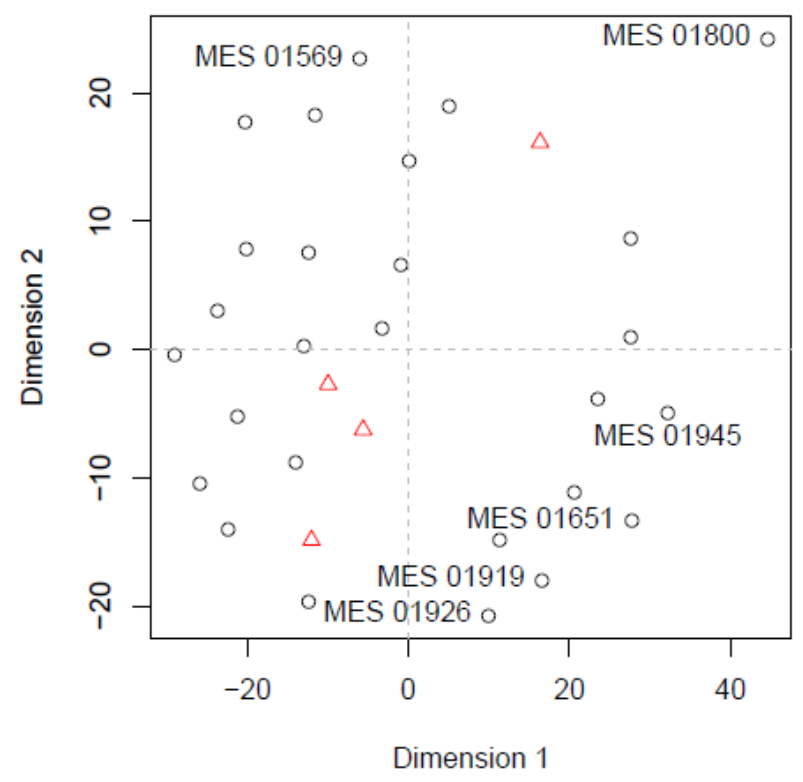

Figuur 14. Sammon plot voor de verschillende champignonisolaten, gebaseerd op de vluchtige verbindingen. Metaboliet gehalten werden loggeschaald voordat de afstanden werden berekend. Sommige extreme monsters worden bij naam genoemd. Referentieras A15 wordt aangegeven met rode driehoekjes.

\subsubsection{Polaire verbindingen}

Ook voor de polaire verbindingen waren de data relatief schaars in die zin dat veel metabolieten slechts in een beperkt aantal monsters werden gevonden. Dit kan een problem opleveren bij het zoeken naar correlaties tussen de aanwezigheid van metabolieten en smaakattributen. De meerderheid van de polaire metabolieten is afwezig in $50 \%$ van de monsters.

Dat laat overigens nog een tamelijk grote groep met metabolieten die aanwezig zijn in alle monsters. Het zou echter zo kunnen zinn dat smaak in grote mate wordt beïnvloed door metabolieten die afwezig zijn in veel van de variëteiten. Die zouden dus over het hoofd worden gezien als we ons alleen richten op de metabolieten die altijd aanwezig zijn. Het is moeilijk om te beslissen waar precies de grens zal liggen. In de

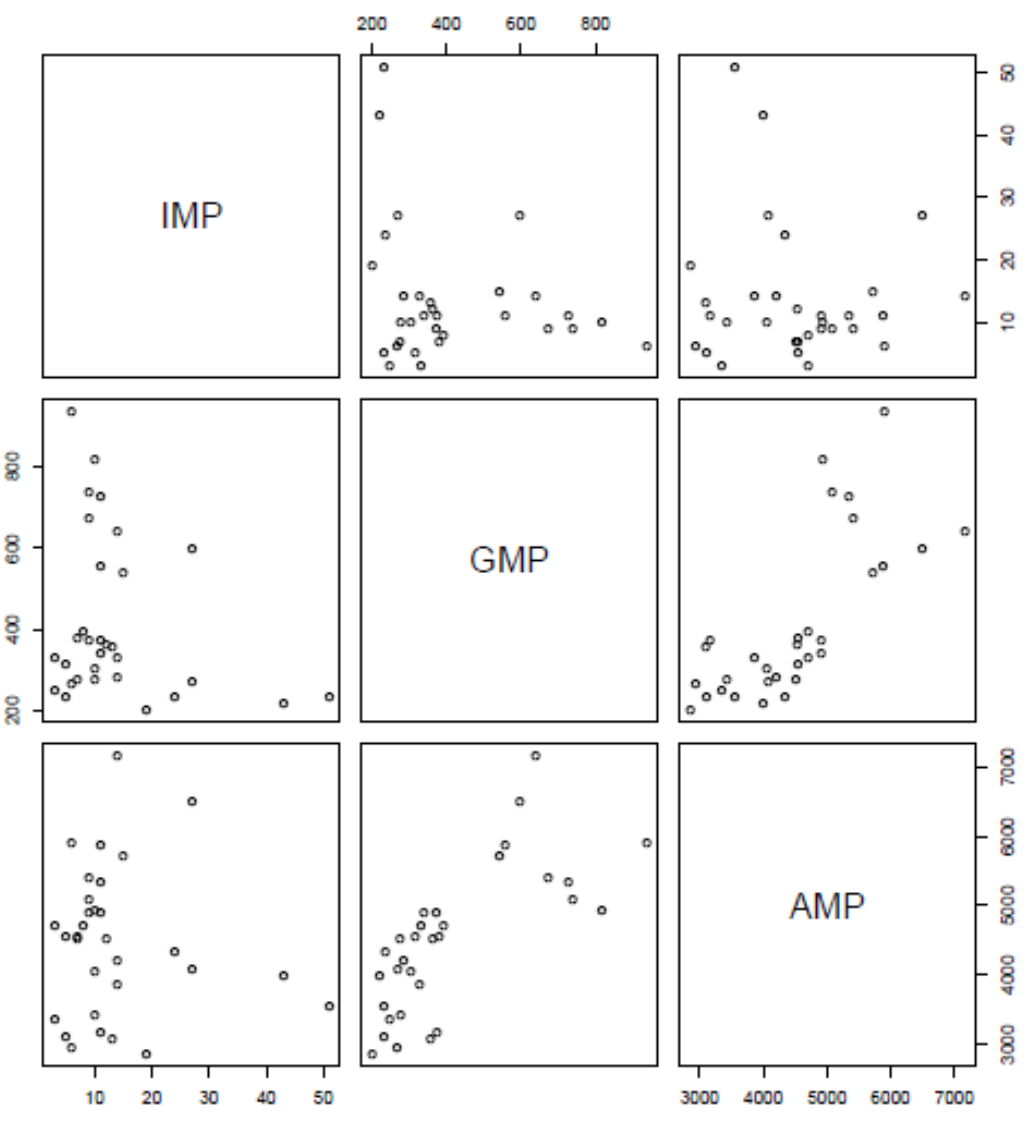

Figuur 15. Scatterplots voor de individuele nucleotiden in de verschillende variëteiten champignons. 
dataset worden in dit geval alle metabolieten behouden die aanwezig zijn in ten minste de helft van de monsters. De mate van verschil tussen de monsters is weergegeven in een Sammon plot (Figuur 16). Monsters die sterk afwijkend zijn, worden met collectienummer weergegeven.

\section{Polar compounds}

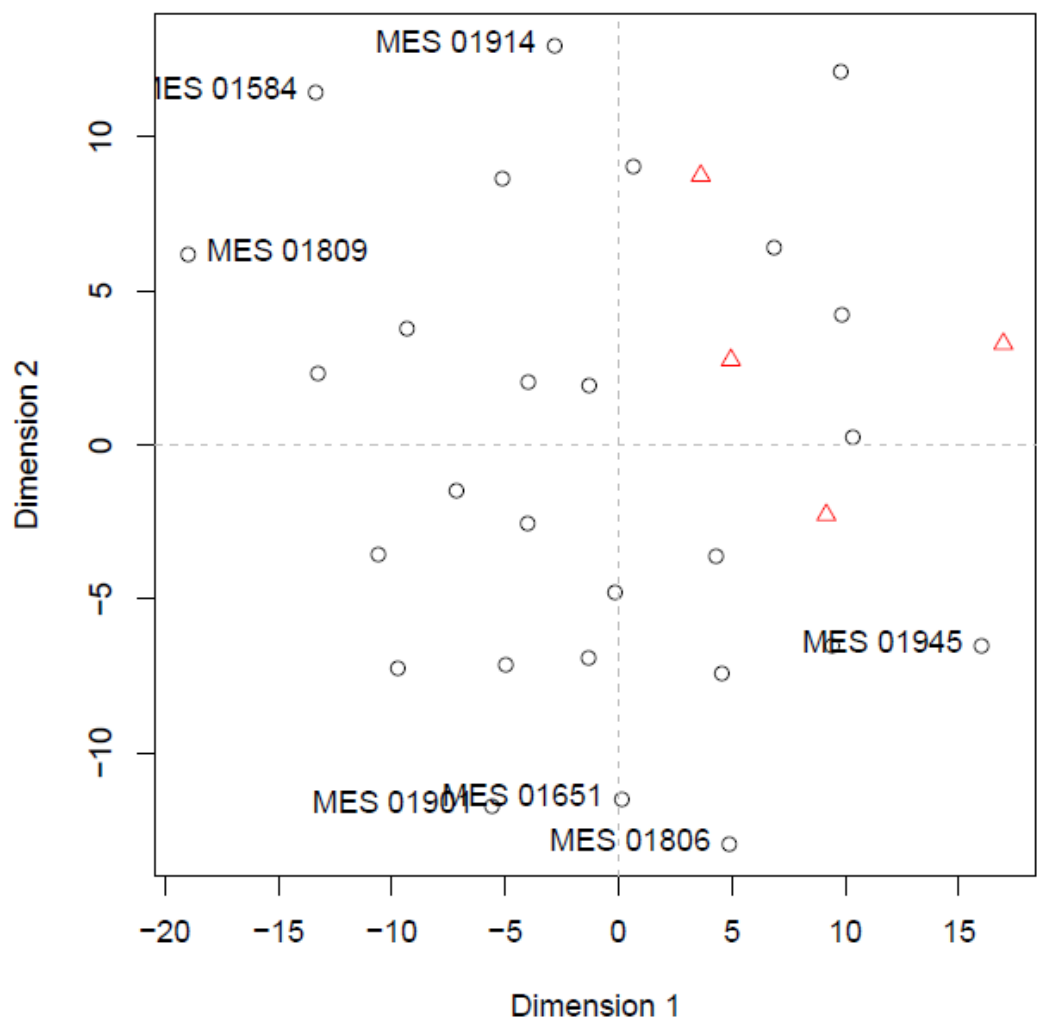

Figuur 16. Sammon plot die de onderlinge verschillen tussen wildisolaten van champignons weergeeft voor wat betreft polaire metabolieten (na log transformative). De rode driehoekjes geven de herhalingen van referentieras A15 aan. Sommige extreem afwijkende wildisolaten worden genoemd. 


\section{$5 \quad$ Koppeling van smaak attributen aan metabolieten}

In dit hoofdstuk word teen poging beschreven om de smaakattributen te koppelen aan metabolietgehalten. Een aantal variëteiten zijn afwezig uit de dataset in één of meer van de 4 metaboliet datasets (vluchtige verbindingen, polaire verbindingen, mannitol en de nucleotide. Deze worden dus niet in de berekeningen meegenomen.

Wederom hebben we twee mogelijkheden; gebruik maken van de scores voor de smaakattributen op een absolute schaal of gebruik maken van de scores ten opzichte van A15

\subsection{Gebruik makend van scores voor smaakattributen op een absolute schaal}

In deze dataset hebbben we ook waarden voor A15 monsters. Dit leidt tot een dataset met 154 metabolieten en 23 champignonvariëteiten.

\subsubsection{Correlatie analyse}

De correlaties tussen de smaakattributen (op een absolute schaal) en de gegevans van de 4 metabolietensets worden weergegeven in Figuren 17 tot 19. Alle metabolietgehalten zijn gebuikt op log-schaal. Blauwe stippen geven een positieve correlatie aan tussen een metaboliet en een smaakattribuut, terwijl een oranje stip een negatieve correlatie aanduidt. De intensiteit van de kleuren geeft de mate van correlatie weer.

\subsubsection{Linear modeling}

Voor het voorspellen van smaakattributen is in eerste instantie gebruik gemaakt van uitsluitende de polaire metabolieten. Voor een voorspellend model is gebruik gemaakt van een lasso model. Alle voorspellende variabelen zijn log getransformeerd en vervolgens genormaliseerd op het gemiddelde en de standard variance. De prediction errors uit de gefitte lasso modellen zijn te zien in Figuur 20. In sommige gevallen zijn de prediction errors laag (bij de attributen "bitter", "prikkelend", "aroma.aanwezigheid"), en in sommige gevallen hoog ("vleesbouillon.aroma"). De hogere foutmarges komen meestal overeen met een grotere standaard deviatie (de blauwe lijnen), hetgeen suggereert dat de lage foutmarges gekoppeld zijn aan de mate van variabiliteit in de data set.

Jammer genoeg is het resultaat niet goed. De modellen voor de verschillende smaakattributen hebben weinig voorspellende waarde.

\subsection{Smaakattributen relatief tot referentie ras A15.}

In deze benadering hebben we minder champignonisolaten gebruikt, aangezien de data relatief zijn tot referentieras $\mathrm{A} 15$.

\subsubsection{Correlatie analyse}

De correlatie tussen de smaakattributen (op een schaal relatief tot A15) en de vier datasets met metabolieten wordt getoond in Figuur 21 tot 23. Alle metabolite gehalten zijn gebruikt op log schaal.

\subsubsection{Lineaire modellering}

Dezelfde berekeningen als in paragraaf 5.1.2. zijn uitgevoerd met de data set relatief tot A15. De prediction errors die daar uit zijn voortgekomen zijn te zien in Figuur 24. Voor sommige smaak attri- 


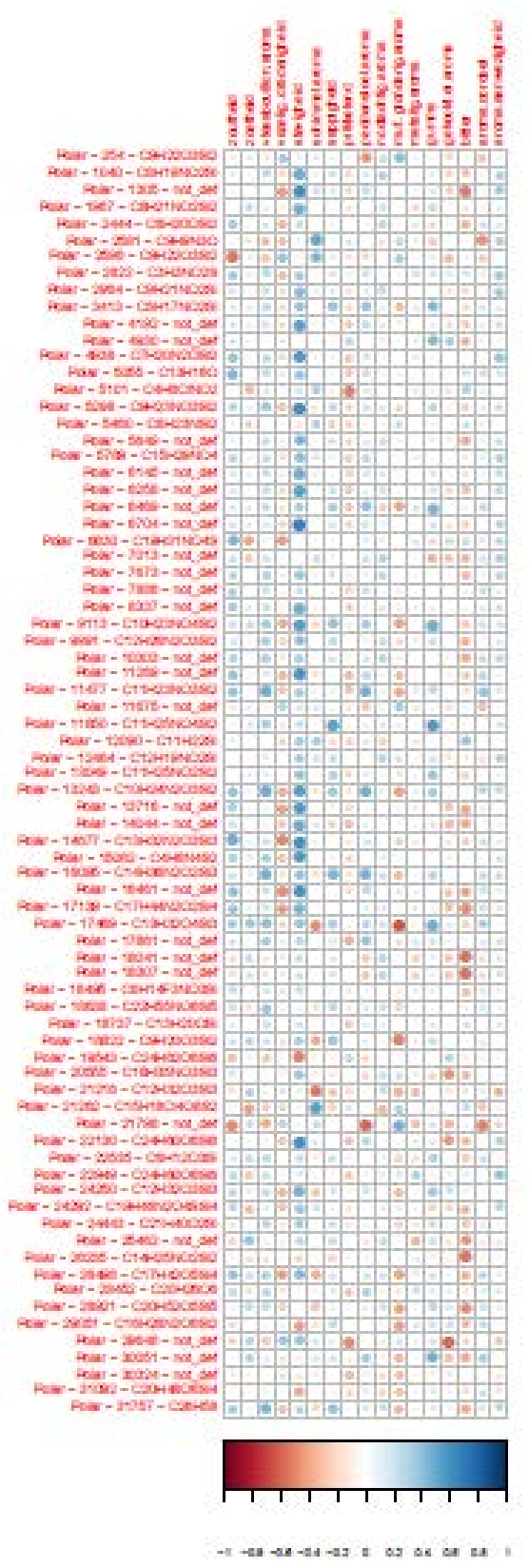

Figuur 19. Correlatie tussen gehalten aan polaire metabolieten en smaakattributen.

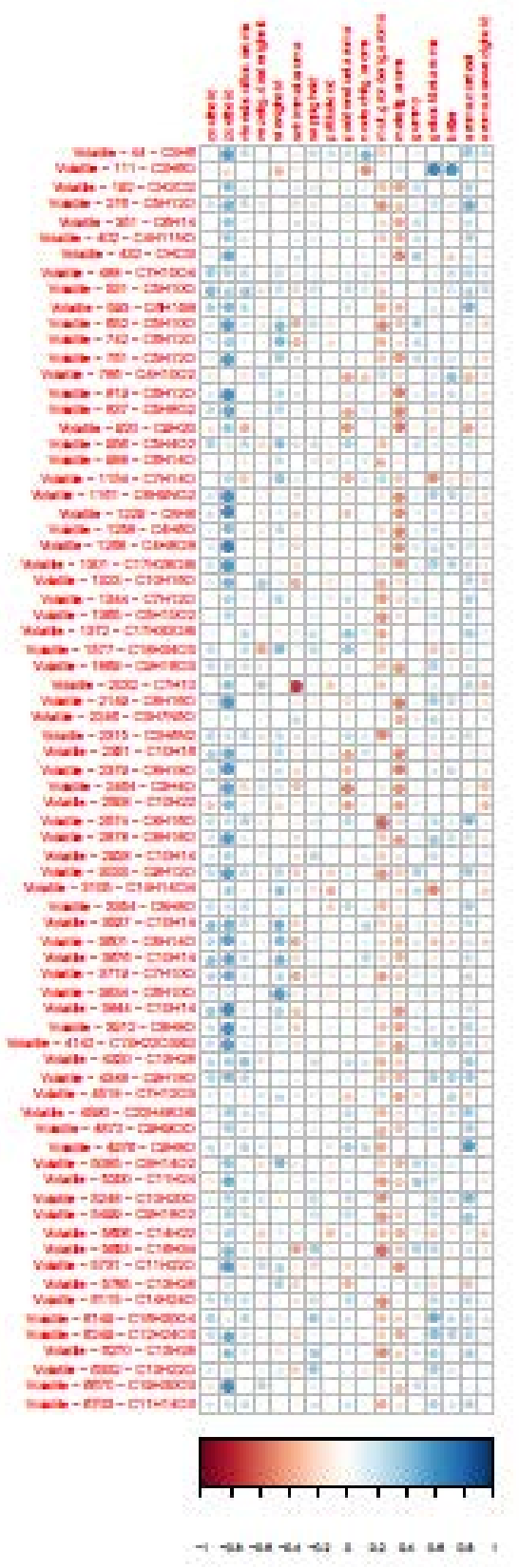

Figuur 19. Correlatie tussen gehalten aan vluchtige verbindingen en smaaattributen.

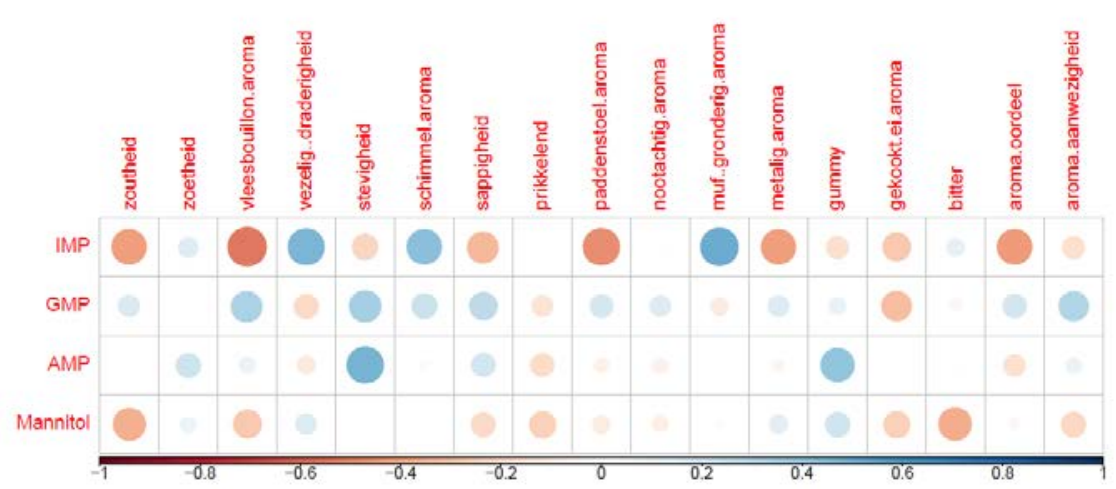

Figuur 19. Correlatie tussen individuële metabolite gehalten (nucleotides en mannitol en smaakattributen 


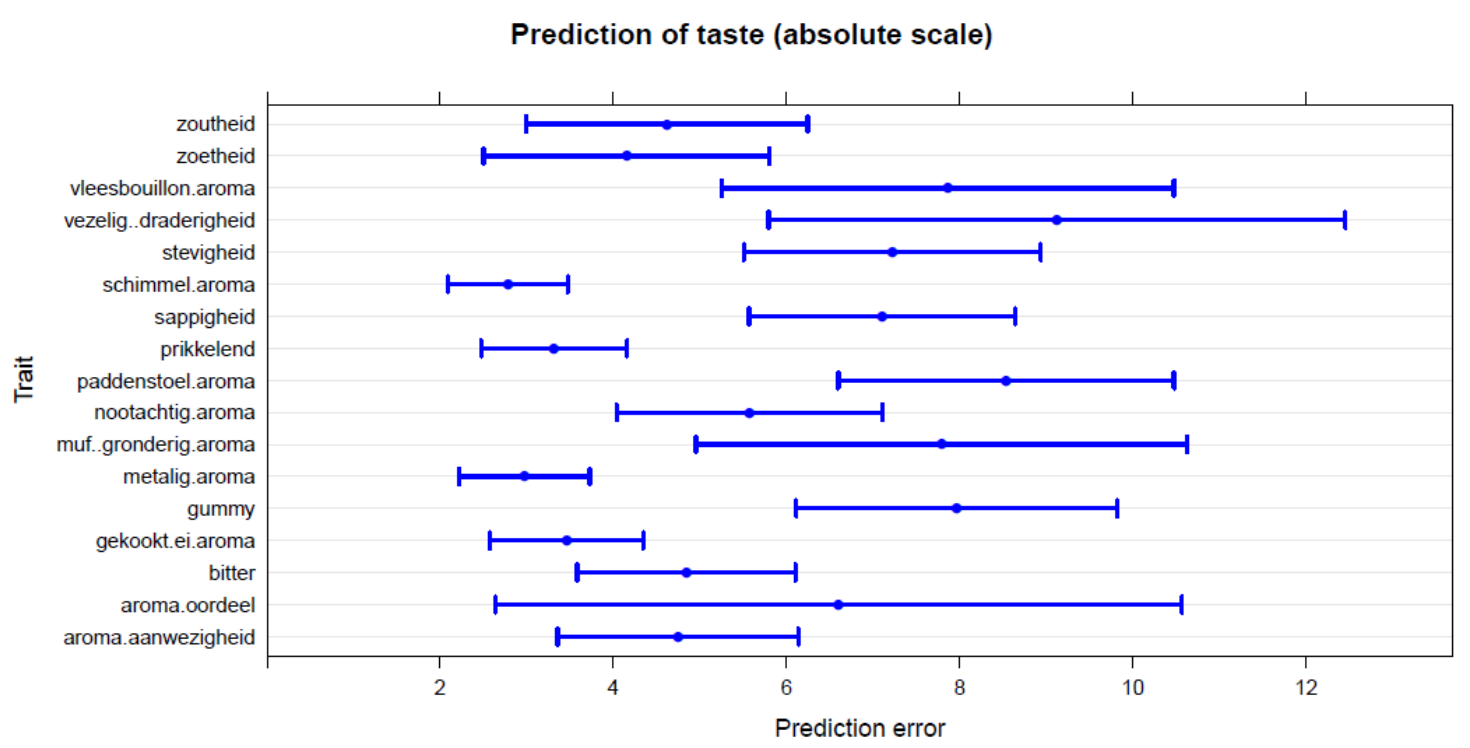

Figuur 20. Prediction errors, uitgedrukt in standard deviaties, in voorlopige lineaire modellen voor smaakvoorspelling.

buten in Figuur 24 ("schimmel.aroma", "prikkelend", "gekookt.ei.aroma") lijken de resultaten een beetje beter, maar ze liggen nog steeds binnen de regio van de standaard deviatie. Alleen "schimmel.aroma" heeft een upper confidence limit die kleiner is dan één (en dus beter voorspelt dat de standaard deviatie). 


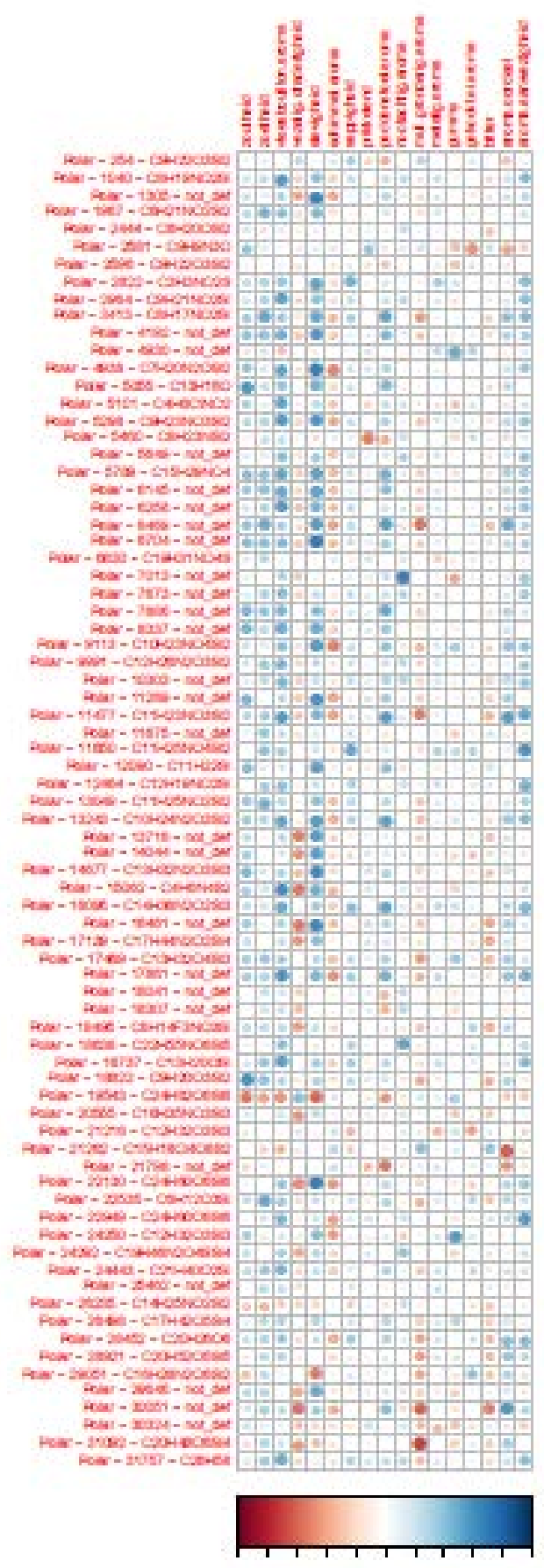

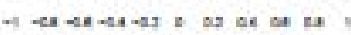

Figuur 23. Correlatie tussen individuële polaire metabolieten en smaakattributen (relatief t.o.v. A15).

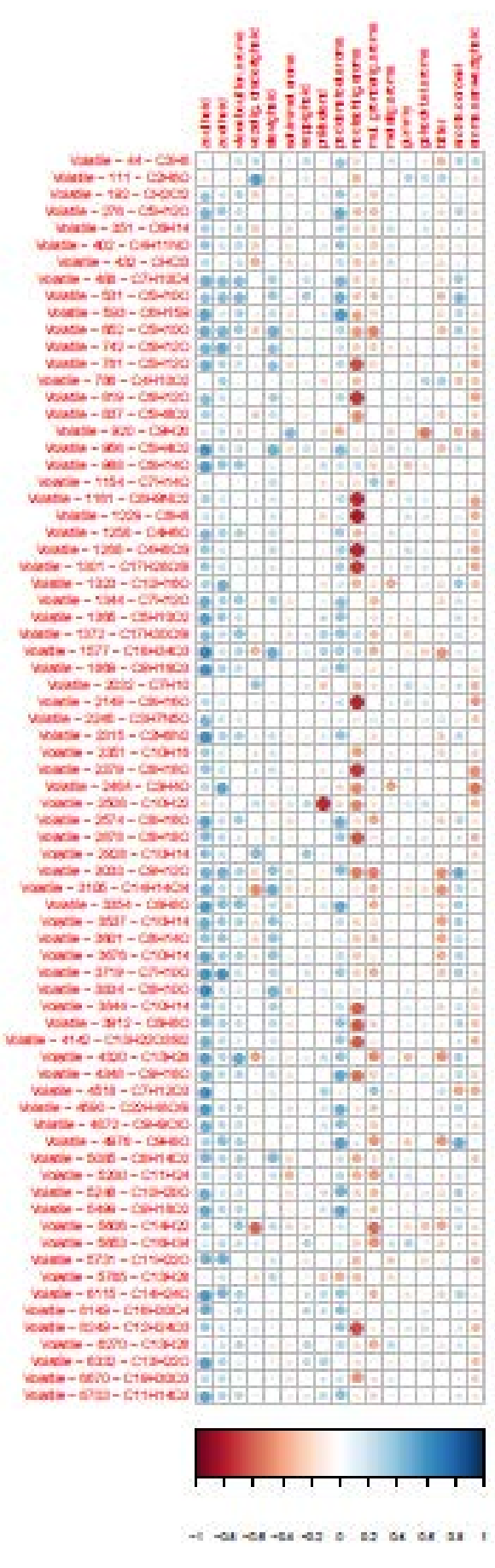

Figuur 23. Correlatie tussen vluchtige verbindingen en smaakattributen ( relatief t.o.v. A15

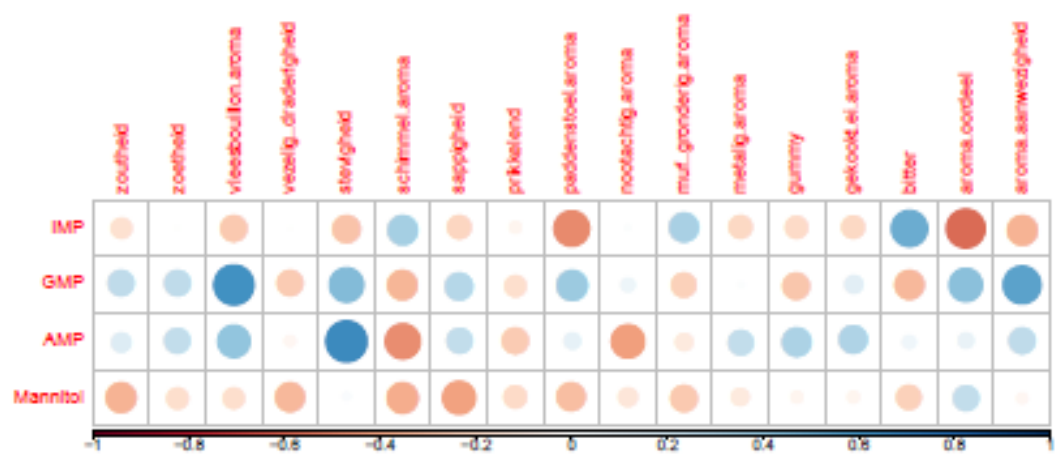

Figuur 23. Correlatie tussen mannitol en nucleotiden en smaakattributen (relatief t.0.v. A15. 


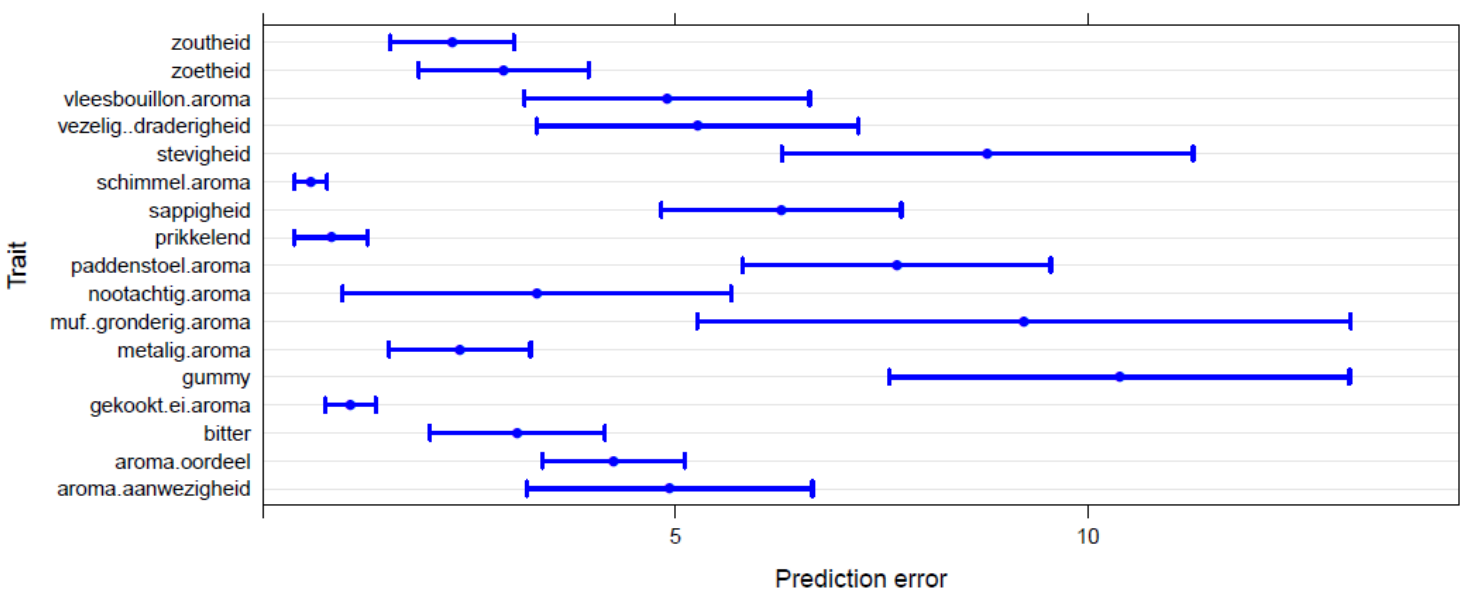

Figuur 24. Prediction errors, uitgedrukt in aantal keer de standard deviatie, in voorlopige lineaire modellen voor voorspelling van smaakattributen op basis van metabolite data. Smaak attributen zijn genormaliseerd relatief t.o.v. A15.

\subsection{Conclusies}

Uit de statistische analyse en het opstellen van lineaire smaakmodellen kunnen de volgende voorlopige conclusies worden getrokken:

- Smaakattributen moeten worden geanalyseerd op een schaal relatief tot de A15 referentie die in elke sessie van het sensorisch panel aanwezig was. Op die manier kan de variatie tussen leden van het smaakpanel en tussen de sessies enigszins worden beperkt

- Om nauwkeurige waarden voor smaakattributen te verkrijgen is mogelijk een geavanceerdere statistische methode nodig dan het werken met gemiddelden; verschillen tussen leden van het sensorisch panel spelen een grote rol.

- De bereiding van de champignons heeft een groot effect op de concentraties van de metabolieten. Er werden alleen analyses op gestoomde monsters uitgevoerd, aangezien het sensorisch panel ook gestoomde champignons analyseerde.

- Er zijn enkele correlaties vastgesteld tussen metabolieten en smaakattributen.

- Voorspellingen van smaakattributen gebaseerd op metaboliet concentraties met behulp van linaire modellen waren niet erg succesvol. 


\section{Pogingen om de waarnemingen door het sensorisch panel te verbeteren.}

In een tweede experiment is geprobeerd om de variatie in de respons van het sensorisch-smaakpanel te verminderen, door:

- Veel minder rassen aanbieden aan de smaakpanels

- Champignonrassen op minder attributen te beoordelen

- Rassen met grootst mogelijk verschil in smaak aanbieden

- Interne herhalingen aanbieden als extra controle.

\subsection{Teelt van champignonrassen.}

Teneinde veel minder champignonrassen aan te bieden aan het sensorisch panel en om rassen met het grootst mogelijke verschil in smaak aan te bieden is een selectie gemaakt van isolaten op basis van de resultaten zoals weergegeven in Figuur 16. Tabel 4 geeft een overzicht van de geselecteerde stammen. Deze stammen werden in 3 opeenvolgende teeltproeven geteeld met commercieel verkrijgbare compost en dekaarde in de periode eind-maart tot begin juni 2018. In alle gevallen werden uitsluitend champignons geoogst in de eerste vlucht aangeboden aan het sensorisch panel.

Tabel 4. Overzicht van stammen met de grootst mogelijke verschillen in smaak ten opzichte van referentieras A15.

\begin{tabular}{|l|l|} 
Behand. & Coll. Nr. \\
\hline $\mathbf{1}$ & MES-01800 \\
\hline $\mathbf{2}$ & MES 01733 \\
\hline $\mathbf{3}$ & MES 01584 \\
\hline
\end{tabular}

\subsection{Beoordeling door het sensorisch panel}

Het sensorisch panel heeft van alle 3 teeltproeven de champignons op smaakattributen beoordeeld. De leden van het sensorisch panel kregen telkens 6 porties champignons blind ter beoordeling; drie wildisolaten in duplo. Champignons werden 4 minuten gestoomd op $100^{\circ} \mathrm{C}$ in een stoomoven voordat ze aan het sensorisch panel werden aangeboden. Figuur 25 geeft een overzicht van de resultaten. Hoewel telkens dezelfde rassen zijn aangeboden aan het sensorisch panel, zijn er toch verschillen tussen de sessies. Bijvoorbeeld, smaak attribuut "vezelig/draderigheid" geeft in één van de drie testen een significant verschil tussen de wildisolaten en in de overige twee testen niet. Smaakattribuut "vleesbouillon aroma" geeft in twee van de drie testen een significant verschil tussen de verschillende wildisolaten.

\subsubsection{Statistische analyse van de resultaten}

Figuur 26 geeft een overzicht van de variatie in de resultaten van het sensorisch panel zoals geanalyseerd middels principal component analysis (PCA). In het linker paneel zijn met kleur de verschillen aangegeven tussen de drie geteste wildisolaten. In het middelste paneel zijn met kleur de verschillen aangegeven tussen de drie sessies van het sensorisch panel. In het rechterpaneel zijn met kleur de verschillen aangegeven tussen de leden van het sensorisch panel. Er is een grote mate van variabiliteit in waardering van de smaak attributen tussen de leden van het sensorisch panel. 
In essentie zijn uit deze dataset slechts voor 5 smaakattributen significante verschillen tussen de drie wildisolaten aan te wijzen; stevigheid, gummy, vezeligheid-draderigheid, zoutheid en metalig aroma.
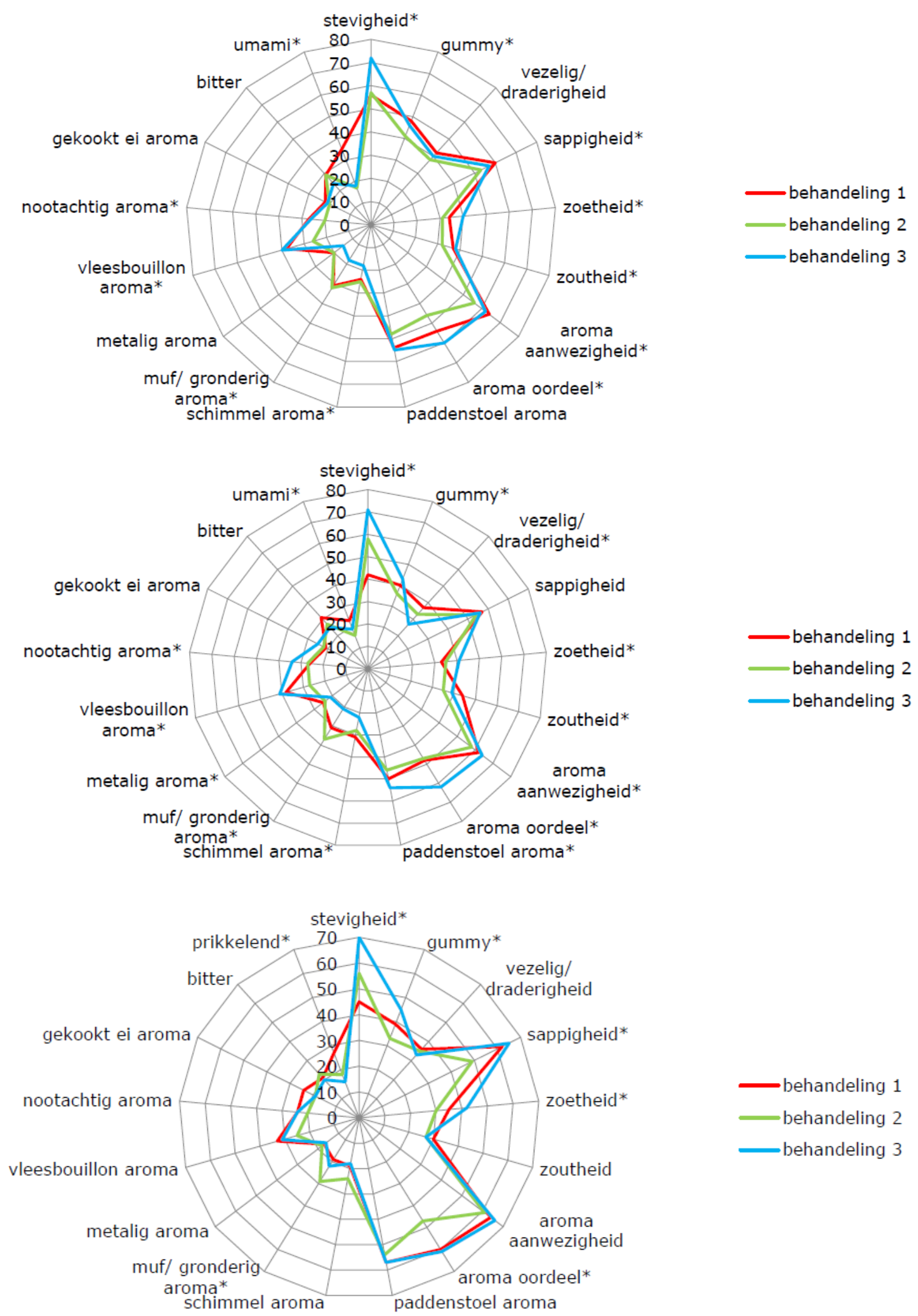

—behandeling 1

behandeling 2

behandeling 3

Figuur 25. Resultaten voor de smaakbeoordelingen voor behandeling $\mathbf{1}$ t/ $\mathbf{m} \mathbf{3}$ uit de eerste (bovenste), tweede (middelste) en derder (onderste) teeltproef. Significante verschillen zijn met een * aangegeven. 
Product

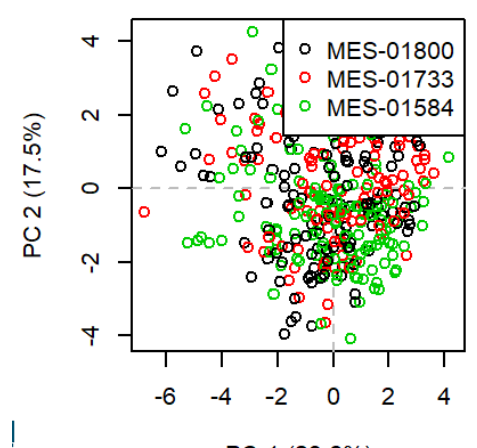

Study

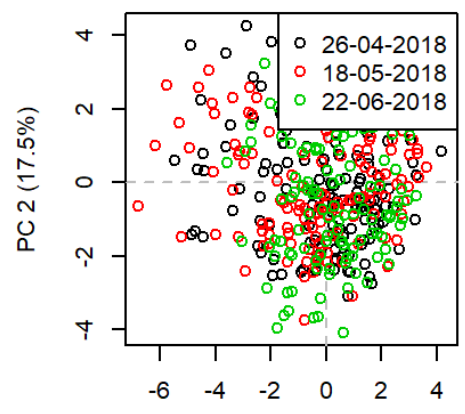

PC $1(23.6 \%)$

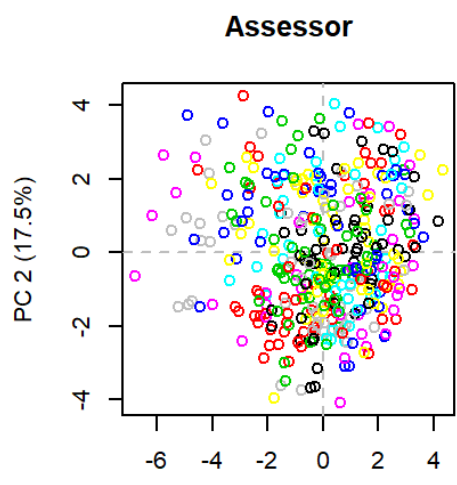

PC $1(23.6 \%)$

Figuur 26. Resultaten van een principal component analyse van de resultaten van het sensorisch panel. Het linker panel geeft weer hoe ieder panellid de verschillende wildisolaten heeft beoordeeld. Het middelste panel geeft de verschillen tussen de die sessies weer. Het rechter panel geeft de verschillen tussen de panelleden weer.

\subsection{Analyse van de metabolieten}

Tijdens de drie sessies van het sensorisch panel zijn gestoomde champignons in vloeibare stikstof ingevroren voor analyse van de metabolieten. De bespreking van de resultaten van deze analyse richt zich vooral op die metabolieten waarvan bekend is dat ze bijdragen aan de smaak van champignons. Figuur 27 toont de resultaten van de analyse op gehalten aan nucleotiden. De groene kolommen staan voor de gehalten van behandeling 1 (wild isolaat MES01800). Opmerkelijk is dat in de champignons die in de sessie van het sensorisch panel op 26-4 zijn aangeboden het gehalte aan IMP veel hoger ligt dan in de champignons van behandeling 1 die op andere sessies werden aangeboden. Vergelijkbare verschillen doen zich voor bij andere sessies voor de nucleotiden AMP en GMP.

Ook voor het gehalte aan mannitol (Figuur 28) is variatie gevonden. Met name voor behandeling 3 (MES 01584) is in één van de sessies van het sensorisch panel een hoger gehalte gevonden dan in de andere twee sessies. Het gehalte aan glutaminezuur (Figuur 29) vertoont eveneens een aanzienlijke variatie.

Figuur 30 toont de resultaten van een principal component analyse van de variatie in de vluchtige verbindingen aanwezig in de champignons die aan het sensorisch panel zijn aangeboden. Hierin is te zien dat er aanzienlijke verschillen bestaan tussen de champignons van eenzelfde behandeling die in de sessies aan het sensorisch panel zijn aangeboden. Dergelijke verschillen worden mede veroorzaakt door verschillen in gehalten aan vluchtige verbindingen zoals 3-octanone en 1-octen-3-ol (zie Figuur 31. Linear mixed model analysis met FDR corrective voor de p-waarden toont aan dat voor 25 metabolieten significante verschillen werden gevonden tussen de 3 wildisolaten. Het betrof 3 vluchtige verbindingen (2-pentenal, benzaldehyde en benzylalcohol) en 22 polaire verbindingen (zoals fumaraat, alanine, lyxonic acid en ornithine). Vanwege de grote variatie in gehalten vertoonde geen enkele van de metabolieten significante verschillen tussen de sessies.

\subsection{Koppeling van smaak attributen aan metabolieten}

In een poging om smaakattributen te koppelen aan gehalten aan metabolieten is een correlatieanalyse uitgevoerd (Figuur 32). Bij wijze van voorbeeld; methionine is positief gecorreleerd met smaak attributen stevigheid, gummy, zoetheid en aroma oordeel. Methionine is negatief gekoppeld met schimmelaroma en metalig aroma. $\mathrm{Er}$ is vervolgens geprobeerd om met behulp van een statistische methode (quasibinomial GLMM analysis) geprobeerd om de correlaties verder te verduidelijken. Hierbij bleek dat 50 metabolieten significant geassocieerd waren met de smaak attribuut "stevigheid" terwijl voor de andere smaak attributen geen enkele metaboliet een associatie had. 

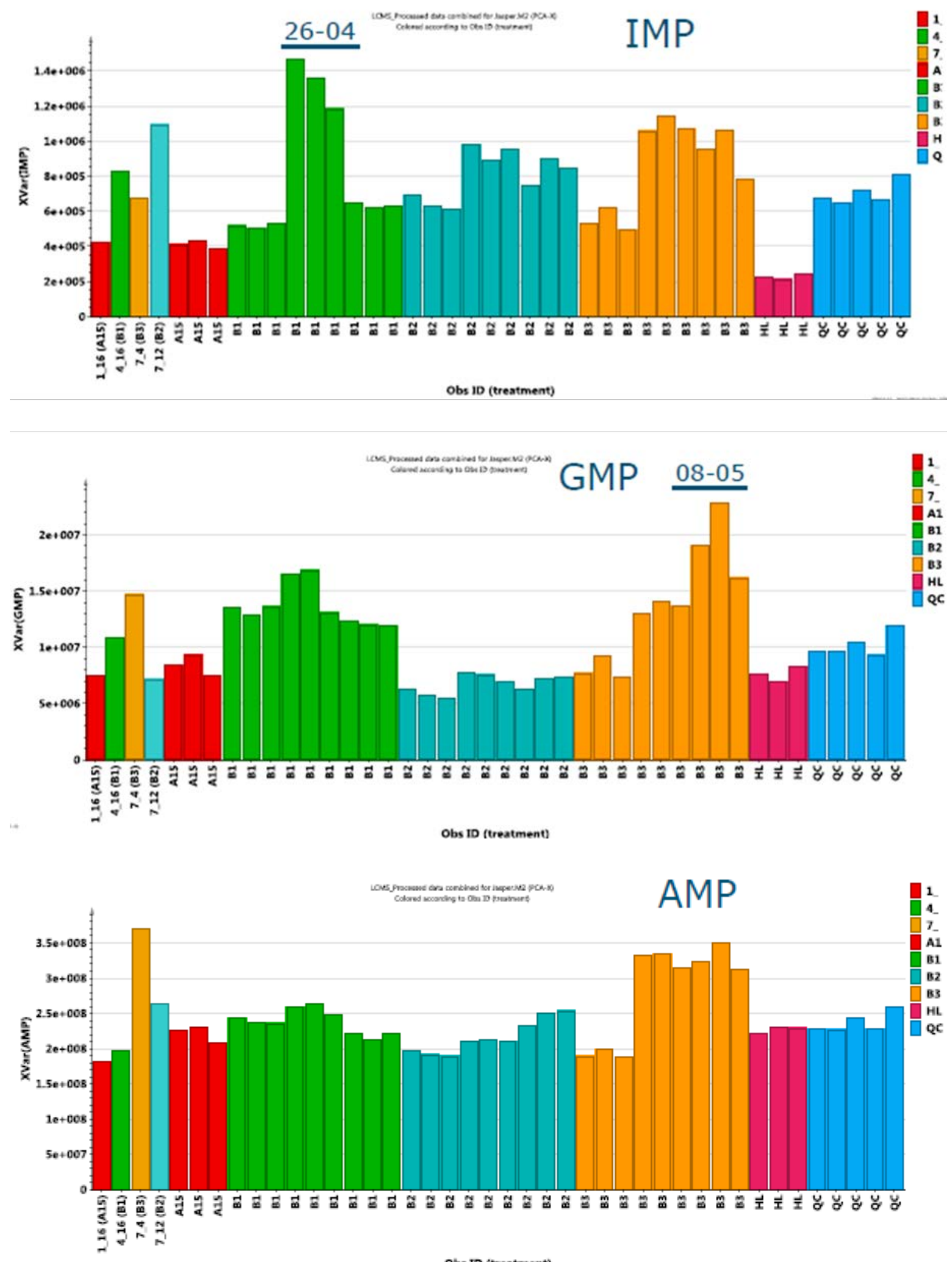

Figuur 27. Resultaten van analyse op nucleotiden. B1, B2 en B3 staan voor respectievelijk behandeling 1, 2 en 3 zoals weergegeven in Tabel 4. 


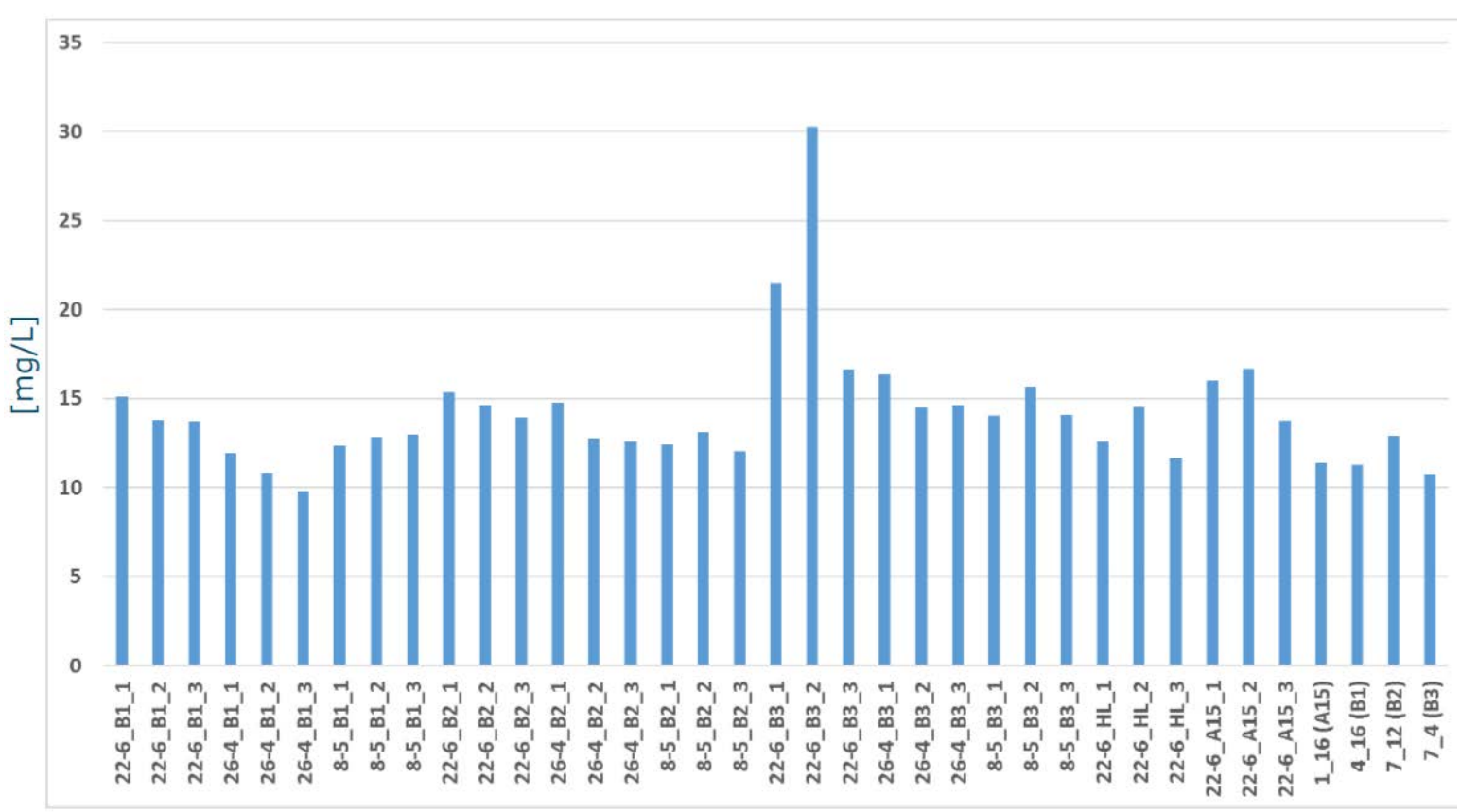

Figuur 29. Verschillen in gehalte aan mannitol in de champignons die zijn aangeboden aan het sensorisch panel. B1, B2 en B3 staan voor respectievelijk behandeling 1, 2 en 3. 26-4, 8-5 en 22-6 staan voor de datums waarop de sessies van het sensorisch panel hebben plaatsgevonden.

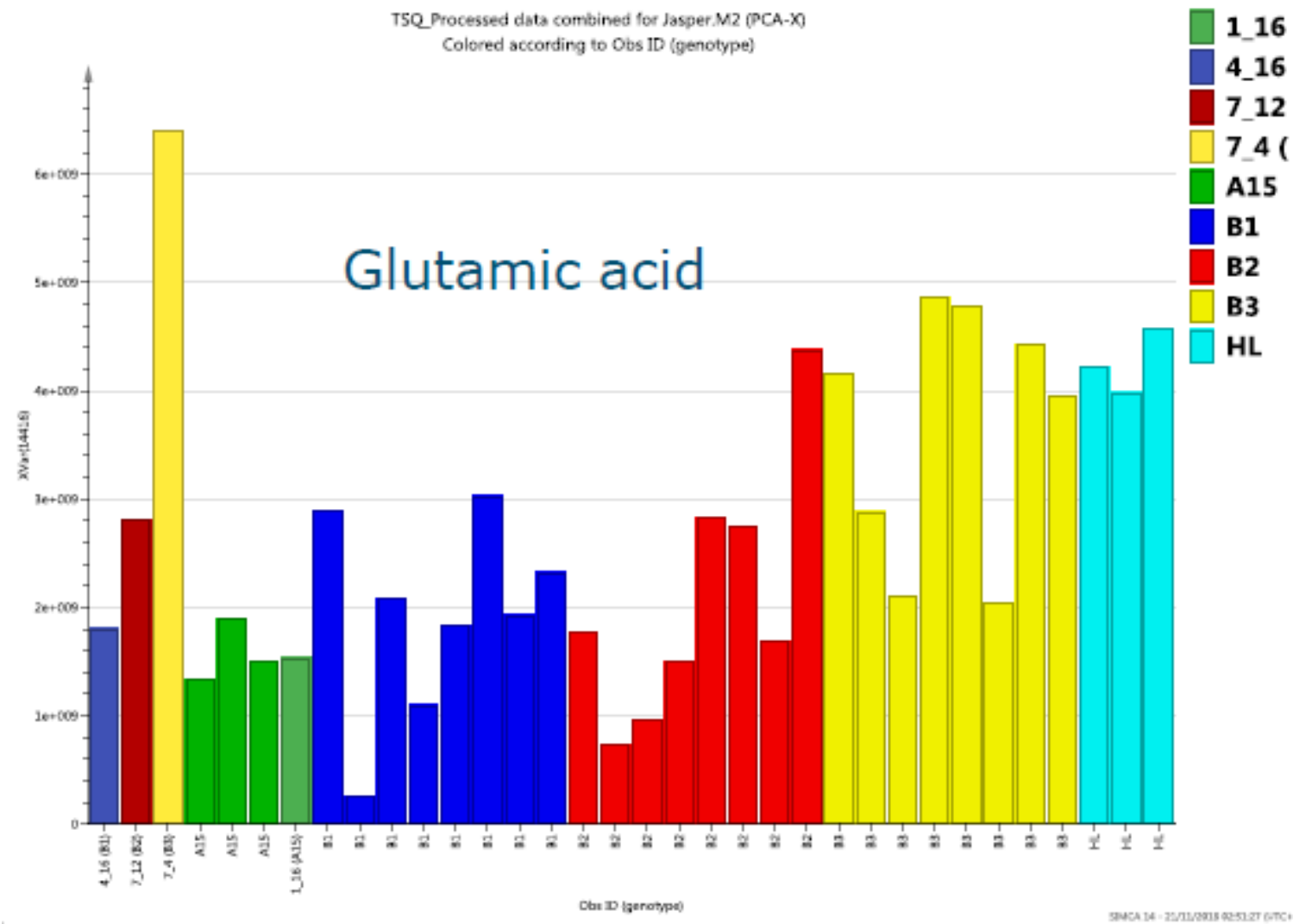

Figuur 28. Verschillen in gehalte aan glutaminezuur in de champignons die zijn aangeboden aan het sensorisch panel. B1 (blauw), B2 (rood) en B3 (geel) staan voor respectievelijk behandeling 1,2 en 3. 


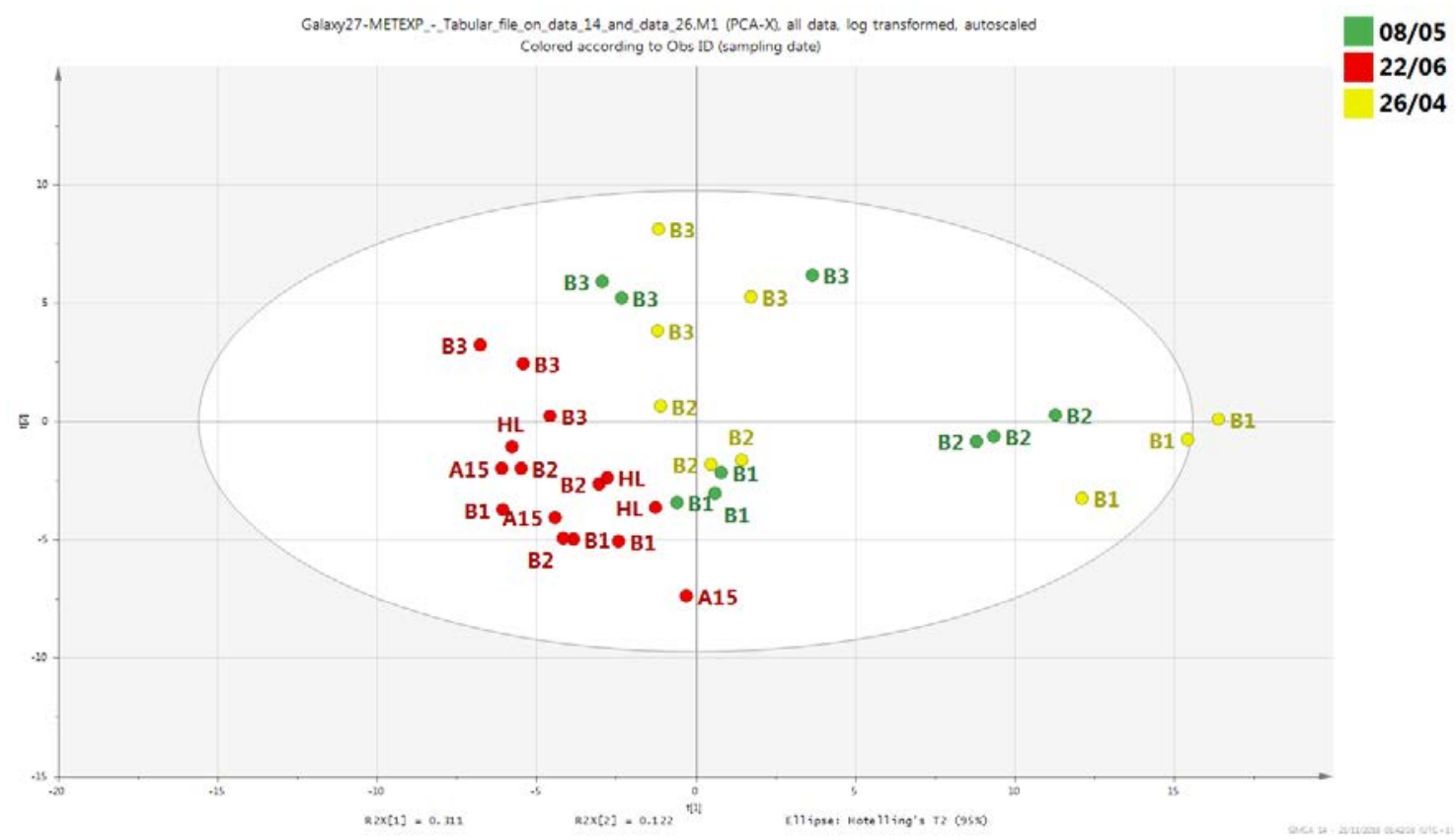

Figuur 30. Principal component analyse van de vluchtige verbindingen in de champignons die zijn aangeboden aan het sensorisch panel. B1, B2 en B3 staan voor respectievelijk behandeling 1,2 en 3. 26-4, 8-5 en 22-6 staan voor de datums waarop de sessies van het sensorisch panel hebben plaatsgevonden.
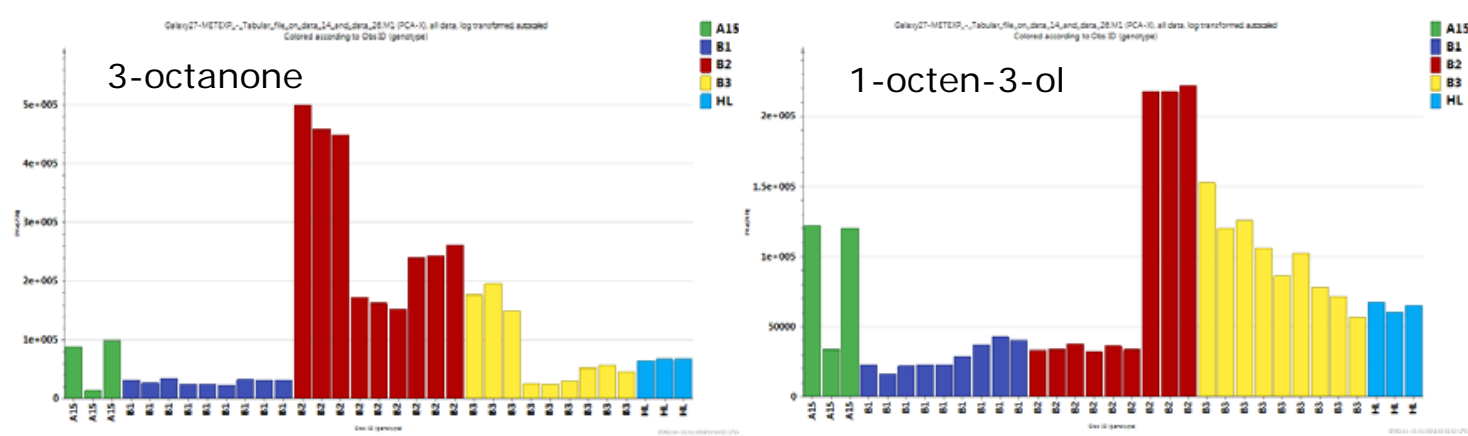

Figuur 31. Verschillen in gehalte aan 3-octanone en 1-octen-3-ol in de champignons die zijn aangeboden aan het sensorisch panel. B1 (blauw), B2 (rood) en B3 (geel) staan voor respectievelijk behandeling 1, 2 en 3. 


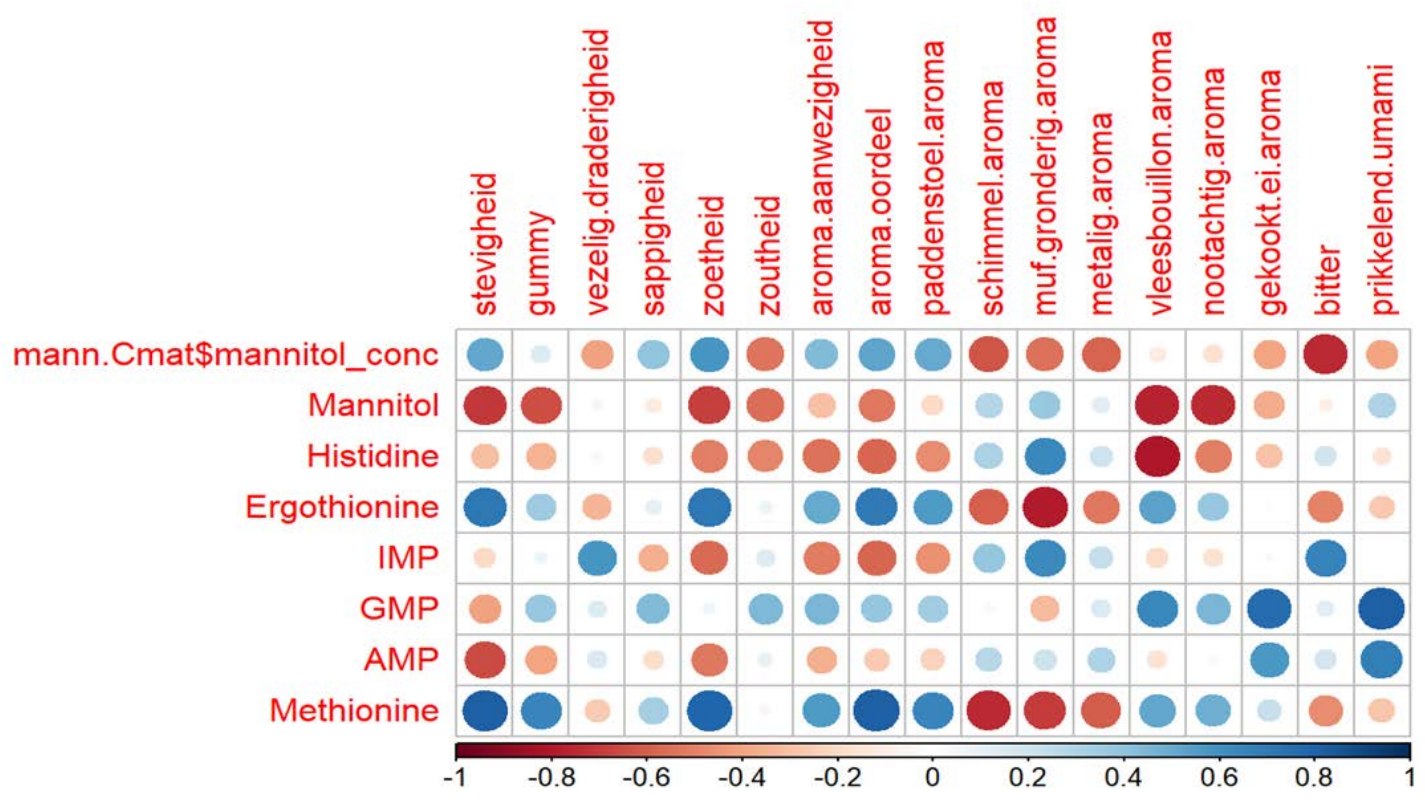

Figuur 32. Correlatie tussen metabolieten en smaakattributen.

\subsection{Conclusie}

Ondanks de mogelijkheden die in de nieuwe proefopzet zijn geïntroduceerd om de mate van variatie als gevolg van verschillen in waardering tussen de leden van het sensorisch panel te verkleinen ( minder rassen die bovendien duidelijk verschillen in smaak, gekoppeld aan het introduceren van duplo's in de beoordeling), bleek het niet mogelijk om een werkend model te ontwikkelen voor het voorspellen van smaakattributen op basis van metabolietsamenstelling. 


\section{Literatuur}

Baars J.J.P, Stijger I., Kersten M. \& Sonnenberg A.S.M., 2015. Differences in taste in button mushroom strains (Agaricus bisporus). PPO/PRI report 2015-3. Beschikbaar via https://library.wur.nl/WebQuery/wurpubs/fulltext/373559 .

Baars J.J.P., Sonnenberg A.S.M., Mumm R., Stijger I. \& Wehrens R., 2016. Metabolites contributing to taste in Agaricus bisporus; . PPO/PRI report 2016-1. Beschikbaar via https://library. wur.nl/WebQuery/wurpubs/fulltext/373560. 

Correspondentie adres voor dit rapport: Postbus 16

6700 AA Wageningen

T 0317480700

https://www.wur.nl/nl/Onderzoek-

Resultaten/Onderzoeksinstituten/plant-

research/Plant-

Breeding/Onderzoek/Paddenstoelenonderzoek.htm

Rapport WPR-XXXX
De missie van Wageningen University \& Research is 'To explore the potential of nature to improve the quality of life'. Binnen Wageningen University \& Research bundelen Wageningen University en gespecialiseerde onderzoeksinstituten van Stichting Wageningen Research hun krachten om bij te dragen aan de oplossing van belangrijke vragen in het domein van gezonde voeding en leefomgeving. Met ongeveer 30 vestigingen, 5.000 medewerkers en 10.000 studenten behoort Wageningen University \& Research wereldwijd tot de aansprekende kennisinstellingen binnen haar domein. De integrale benadering van de vraagstukken en de samenwerking tussen verschillende disciplines vormen het hart van de unieke Wageningen aanpak. 


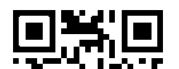

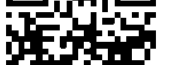

